\title{
Bronchoalveolar lavage as a diagnostic procedure: a review of known cellular and molecular findings in various lung diseases
}

\author{
Kevin R. Davidson ${ }^{1}$, Duc M. Ha ${ }^{1,2,3}$, Marvin I. Schwarz ${ }^{1}$, Edward D. Chan ${ }^{1,2,4}$ \\ ${ }^{1}$ Division of Pulmonary Sciences \& Critical Care Medicine, University of Colorado Anschutz Medical Campus, Aurora, Colorado, USA; ${ }^{2}$ Rocky \\ Mountain Regional Veterans Affairs Medical Center, Aurora, Colorado, USA; ${ }^{3}$ Institute for Health Research, Kaiser Permanente Colorado, Aurora, \\ Colorado, USA; ${ }^{4}$ National Jewish Health, Denver, Colorado, USA \\ Contributions: (I) Conception and design: KR Davidson, ED Chan; (II) Administrative support: None; (III) Provision of study materials or patients: \\ None; (IV) Collection and assembly of data: None; (V) Data analysis and interpretation: None; (VI) Manuscript writing: All authors; (VII) Final \\ approval of manuscript: All authors. \\ Correspondence to: Edward D. Chan, MD. D509, Neustadt Building, National Jewish Health, 1400 Jackson St, Denver, Colorado 80206, USA. \\ Email: ChanE@NJHealth.org.
}

\begin{abstract}
Bronchoalveolar lavage (BAL) is a commonly used procedure in the evaluation of lung disease as it allows for sampling of the lower respiratory tract. In many circumstances, BAL differential cell counts have been reported to be typical of specific lung disorders. In addition, more specific diagnostic tests including molecular assays such as polymerase chain reaction (PCR) or enzyme-linked immunosorbent assay, special cytopathologic stains, or particular microscopic findings have been described as part of BAL fluid analysis. This review focuses on common cellular and molecular findings of BAL in a wide range of lung diseases. Since the performance of the first lung irrigation in 1927, BAL has become a common and important diagnostic tool. While some pulmonary disorders have a highly characteristic signature of BAL findings, BAL results alone often lack specificity and require interpretation along with other clinical and radiographic details. Development of new diagnostic assays is certain to reinforce the utility of BAL in the future. Our review of the BAL literature is intended to serve as a resource to assist clinicians in the care of patients with lung disorders.
\end{abstract}

Keywords: Bronchoalveolar lavage (BAL); bronchoscopy; cell count differential; lung disease; pneumonitis; signature

Submitted Jan 14, 2020. Accepted for publication Aug 12, 2020.

doi: $10.21037 /$ jtd-20-651

View this article at: http://dx.doi.org/10.21037/jtd-20-651

\section{Introduction}

Bronchoalveolar lavage (BAL) is a common and relatively safe diagnostic procedure for the evaluation of patients with lung disease. It often provides valuable diagnostic information when clinical history, physical exam, routine laboratory testing, pulmonary function testing and radiographic imaging are insufficient to reach a definitive diagnosis. Compared to sputum analysis, BAL allows for targeted sampling of the lower respiratory tract with less microbial contamination from the upper aerodigestive tract.

Since the first lung irrigation was performed through a rigid bronchoscope in 1927, the procedure of BAL has advanced to become safer and better tolerated $(1,2)$. Development of the flexible bronchoscope in 1966 was a major breakthrough as bronchoscopy and BAL are now typically performed under conscious sedation. BAL is frequently paired with other bronchoscopic procedures such as endobronchial or transbronchial biopsies, transbronchial needle aspiration, bronchial brushings, and endobronchial ultrasound-guided needle aspirations. The lavage fluid can be evaluated with a variety of analytical tests including cell counts and differential, cytopathologic analysis, and cultures in addition to specific molecular and immunologic diagnostic tests. 


\section{BAL as a diagnostic procedure}

Several characteristics of BAL fluid have been recognized to predict-with varying degrees of confidence-specific lung disorders. For example, with compatible clinical history and imaging, a lymphocytic-predominant BAL is adequate to support a diagnosis of pulmonary sarcoidosis or hypersensitivity pneumonitis; or in a patient with an acute alveolar opacification on chest imaging, the presence of significant BAL eosinophils can indicate acute eosinophilic pneumonia with a fair degree of certainty (3-6). However, in most instances, although the cell differential findings on BAL often lack specificity, they still may be useful in excluding certain disorders such as diffuse alveolar hemorrhage, eosinophilic lung diseases, and to a lesser degree, certain infections, thus narrowing the differential diagnosis (7). The differential cell count may even be normal in many pulmonary disorders such as chronic obstructive pulmonary disease, asthma, or some cases of drug-induced pneumonitis $(8,9)$. Creating greater complexity, the BAL cell count differential may evolve over time depending on the stage of the disease process such as in hypersensitivity pneumonitis and cases of acute respiratory distress syndrome (ARDS) $(10,11)$. Nevertheless, the BAL cell count and differential pattern often assists clinicians in supporting a particular diagnosis or excluding others, thereby providing helpful clues in challenging cases and improving diagnostic accuracy. In some circumstances, no characteristic cell count and differential patterns are discernable either because of variability of cell counts seen in the disease process or limited data on BAL cell counts reported in the literature. Transbronchial biopsy and especially surgical lung biopsy retain a prominent role in the formal diagnosis of several lung diseases where BAL findings are nondiagnostic $(12,13)$.

BAL is often performed to obtain respiratory samples in suspected infections for microbiologic culture and analysis when patients are unable to expectorate sputum even after attempt at sputum induction. However, after the initiation of antibiotics, even BAL loses sensitivity for many bacterial pathogens and becomes insensitive for fastidious microbes (14). Newer diagnostic techniques including polymerase chain reaction (PCR) and other molecular assays enhance the role of BAL for identifying specific microbial infections. Among immunocompromised patients who are vulnerable to a wider range of pathogens and may not exhibit classic symptoms or radiographic findings, BAL is particularly useful; e.g., for the diagnosis of pneumocystis pneumonia.
Additionally, more recent diagnostic techniques such as matrix-assisted laser desorption/ionization time-of-flight mass spectrometry (MALDI-TOF) and PCR coupled to electrospray ionization mass spectrometry (PCR/ESIMS) both show potential to provide rapid microbiologic results of BAL fluid that will enable clinicians to target particular organisms far sooner than conventionally possible $(15,16)$. More recently, whole-genome sequencing, including real-time metagenomic sequencing, of BAL fluid has been used to diagnose and manage viral, bacterial, and fungal pneumonias in critically ill patients with and without immunosuppression $(17,18)$. In addition, shotgun sequencing of BAL fluid has been used to characterize the metagenomics and microbiome of the respiratory tract of lung transplant recipients (19) and patients with chronic lung diseases (20). As whole-genome sequencing becomes more readily available in clinical laboratories, its role in the analysis of BAL fluid will likely increase.

The technique by which BAL is performed, while similar globally, may have geographic variations depending on the institution and region of the world (21). In the United States and Europe, there are efforts to standardize the collection of BAL according to consensus guidelines $(13,22,23)$. The bronchoscope is advanced distally into the bronchopulmonary segment of interest until it occludes the bronchus, thereby "wedging" the scope. Sequential aliquots of normal saline totaling at least $100 \mathrm{~mL}$ (and no more than $300 \mathrm{~mL}$ ) should be instilled and at least 30\% returned for optimal sampling. A minimum $5 \mathrm{~mL}$ (and ideally 10-20 mL) is needed for cellular analysis (13). Strict safety standards are advised including the use of sedatives and anesthetics and diligent monitoring of patients' vital signs, respirations, and oxygenation during the procedure (24). BAL fluid should be collected in a labeled sterile container and transported expediently to the laboratory for analysis (21). Depending on laboratory capabilities, differential cell counts are performed by flow cytometry or manually after filtration or cytocentrifugation techniques (25).

Topical anesthetics such as lidocaine are administered universally in the upper airway, larynx, and lower respiratory tree to provide comfort and decrease cough. Theoretically, there have been concerns that high levels of topical anesthetics could reduce the sensitivity of microbial cultures from the BAL (26). This appears to be true of bronchial washings, but not of BAL (27). Such discrepancy is accounted for by the much higher volumes of sterile saline used during BAL in comparison to bronchial washings, thereby diluting the concentration of any residual 
Table 1 Healthy subjects

\begin{tabular}{ll}
\hline Smoking status & Bronchoalveolar lavage fluid findings \\
\hline Healthy non-smokers & $\begin{array}{l}\text { Macrophage predominant } \sim 85 \% \text { of all white blood cells. Lymphocytes } \sim 10 \%, \sim 5 \% \\
\text { neutrophils, }<1 \% \text { eosinophils, }<1 \% \text { basophils }(28-30)\end{array}$ \\
Healthy smokers & $\begin{array}{l}\text { Smokers have increased cellularity compared to non-smokers. They also have an increased } \\
\text { fraction of pigmented macrophages and decreased fraction of lymphocytes }(29,31)\end{array}$ \\
\hline
\end{tabular}

Table 2 Airway diseases

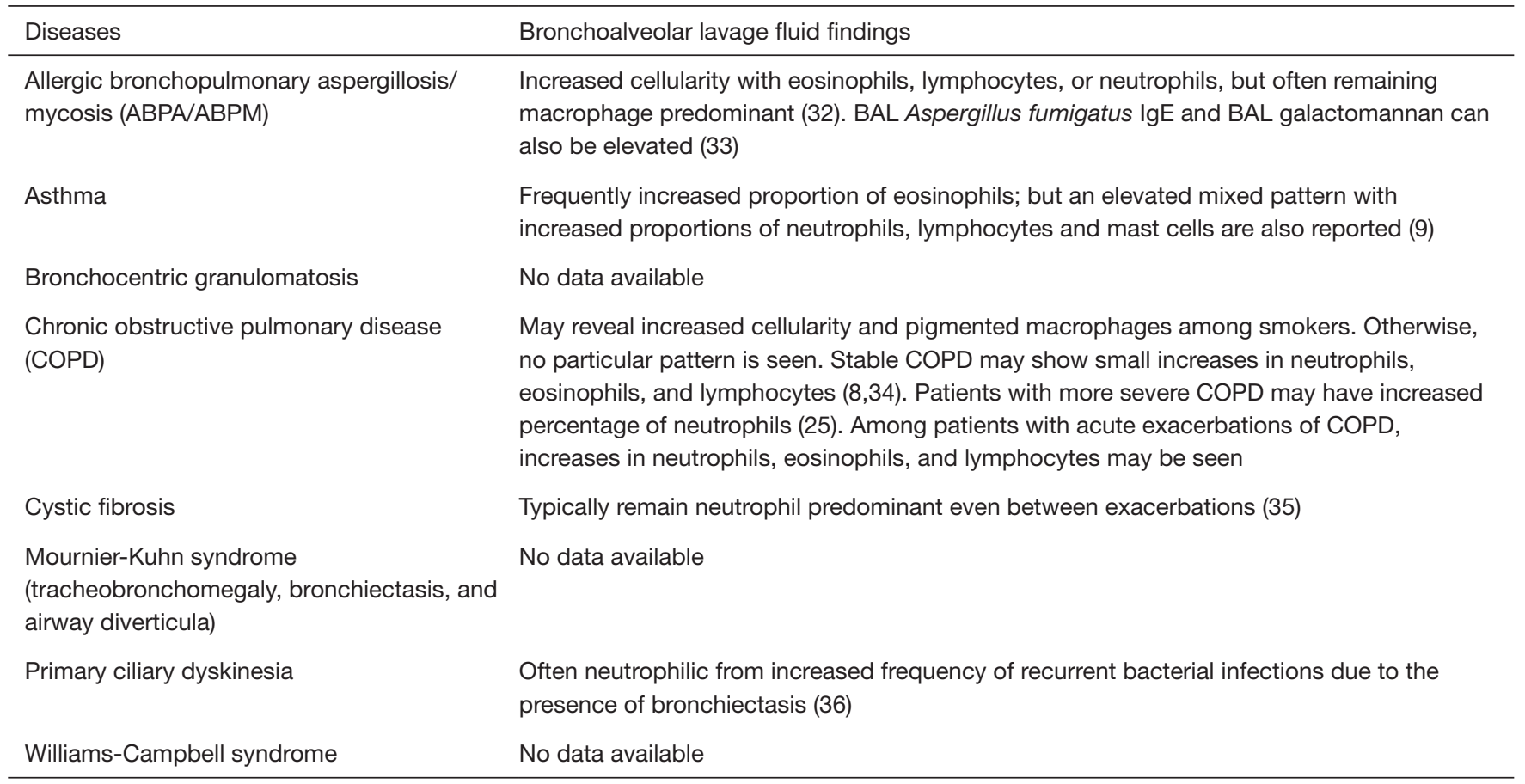

topical anesthetic.

The objectives here are to compile available BAL data categorized by different classes of lung diseases and also to highlight lung disorders where insufficient BAL data exist. We performed comprehensive searches on PubMed to find available data on particular BAL profiles for a given disease using the keywords of BAL, lung lavage, and the names of specific disorders. A further goal is to provide clinicians with a succinct and referenced resource to aid in the evaluation of patients who undergo BAL albeit we acknowledge that in some resource-poor countries, many of the specific molecular tests may not be readily available. The data assembled are focused on the particular patterns of BAL cellularity seen within each disease state. In many cases, there were few published studies and when present, often limited to case reports and series. Not surprisingly, we found very few published articles on BAL data of rare lung diseases or pulmonary toxicities associated with recently developed medications.

The BAL data are organized into the following categories: healthy subjects (Table 1), airways diseases (Table 2), cystic lung diseases (Table 3), pulmonary vasculitides (Table 4), interstitial lung diseases (Table 5), occupational and environmental lung diseases (Table 6), radiation-induced pneumonitis (Table 7), infectious pneumonias (Tables 8-12), drug-induced pneumonitis (Table 13), and miscellaneous lung diseases (Table 14). For infectious pneumonias, we focused primarily on microbiologic and molecular diagnostic testing available. Additionally, we tabulated diseases characterized by particular BAL cell differential (eosinophilic, lymphocytic, or neutrophilic predominance) (Table 15), diffuse alveolar hemorrhage (DAH) due to non- 
Table 3 Cystic lung diseases

\begin{tabular}{ll}
\hline Diseases & Bronchoalveolar lavage fluid findings \\
\hline $\begin{array}{l}\text { Birt-Hogg-Dubé syndrome } \\
\text { Lymphangioleiomyomatosis }\end{array}$ & $\begin{array}{l}\text { No data available } \\
\text { (LAM) }\end{array}$ \\
$\begin{array}{l}\text { biopsies show positivity for HMB45 and smooth muscle actin as well as nodular infiltration of } \\
\text { pulmonary lymphatics with LAM cells (38) }\end{array}$ \\
$\begin{array}{l}\text { Meurofibromatosis } \\
\text { of neurofibromatosis-associated lung fibrosis (39) }\end{array}$ \\
$\begin{array}{l}\text { Sulmonary Langerhans cell } \\
\text { histiocytosis (PLCH, formerly } \\
\text { eosinophilic granuloma) }\end{array}$ & $\begin{array}{l}\text { be lymphocytosis, slight neutrophilia or eosinophilia but these changes are inconsistent. Cells } \\
\text { demonstrating +CD1a (OKT6) in } \geq 5 \% \text { of cells are highly specific for PLCH; although sensitivity for this } \\
\text { cutoff value is low because only } ~ 50 \% \text { of patients show this elevation of CD1a(+) cells (7,40-42). On } \\
\text { immunohistochemistry, cells are typically also CD68 positive and langerin (CD207) positive (43). S-100 } \\
\text { may also be positive but is nonspecific (44). Transbronchial biopsy is insensitive (10-40\% sensitivity) } \\
\text { given patchy lung involvement in PLCH (37). Langerhans cells with distinguishing Birbeck granules may } \\
\text { be seen on electron microscopy of biopsy specimens (45) }\end{array}$ \\
\hline
\end{tabular}

Table 4 Pulmonary vasculitides*

\begin{tabular}{ll}
\hline Diseases & Bronchoalveolar lavage fluid characteristics \\
\hline $\begin{array}{l}\text { Behçet's disease } \\
\text { Cryoglobulinemia }\end{array}$ & $\begin{array}{l}\text { Increased cellularity with increased proportion of lymphocytes. Neutrophils may also be increased (46) } \\
\text { Associated with lymphocyte predominance and overall increased cellularity including subtle elevations } \\
\text { in proportions of neutrophils and occasionally eosinophils }(47,48)\end{array}$ \\
$\begin{array}{l}\text { Eosinophilic granulomatosis } \\
\text { with polyangiitis (EGPA, formerly } \\
\text { Churg-Strauss syndrome) }\end{array}$ & $\begin{array}{l}\text { Typically with increased fraction of eosinophils }(\geq 25 \%)(49) \text {. Transbronchial lung biopsy has low yield } \\
\text { Granulomatous polyangiitis } \\
\text { (GPA, formerly Wegener's } \\
\text { granulomatosis) }\end{array}$ \\
$\begin{array}{l}\text { Goodpasture syndrome } \\
\text { Neutrophil predominance with slight elevation in lymphocytes or eosinophils is seen in analysis of BAL }\end{array}$ \\
\hline
\end{tabular}

*, all will likely have a BAL consistent with diffuse alveolar hemorrhage (DAH).

infectious and infectious causes (Table 16), foamy alveolar macrophages (Table 17), and a tabulation of disorders in which a signature of BAL cellular findings may be diagnostic or relatively so (Table 18). Abbreviations in the tables are defined at the bottom of Table 18. We have elected not to discuss cytologic analysis of BAL to diagnose primary lung cancer or metastatic disease in detail in the scope of this paper.

\section{BAL as a therapeutic procedure}

BAL is almost exclusively used as a diagnostic tool. But a modified BAL-really more of a bronchial washusing smaller aliquots of saline to help dislodge distal mucous plugs is likely the most common therapeutic use, especially in those with a secured airway (endotracheal tube or tracheostomy) but too debilitated to self-expectorate successfully. The best evidence for therapeutic use of BAL is for pulmonary alveolar proteinosis. In this instance, the BAL technique is modified with high volumes of sterile normal saline via a dual lumen endotracheal tube to perform a therapeutic whole lung lavage with removal of heavy lipoproteinaceous sediment from the lungs. This procedure was first described in 1963 with subsequent modifications in technique to optimize patient safety, yield of removed protein and therapeutic benefit (320). Other rare reports of therapeutic lung lavage have been described for exogenous lipoid pneumonia from milk aspiration (321) and another 
Table 5 Interstitial lung diseases

\begin{tabular}{l} 
Diseases \\
\hline Acute eosinophilic pneumonia (AEP) \\
Acute interstitial pneumonia (AIP) \\
Chronic eosinophilic pneumonia (CEP) \\
Cryptogenic organizing pneumonia (COP) \\
Desquamative interstitial pneumonia (DIP) \\
Granulomatous lymphocytic interstitial lung \\
disease (GLILD) \\
Interstitial pneumonia with autoimmune \\
features (IPAF), Connective tissue associated \\
interstitial lung disease (CT-ILD, ILD associated \\
with rheumatoid arthritis, Sjögren's syndrome, \\
scleroderma, dermatomyositis)
\end{tabular}

Bronchoalveolar lavage fluid characteristics

Eosinophilia $>25 \%$, often ranging $37-54 \%(6,53,54)$

Neutrophil predominance with occasional evidence of hemorrhage related to DAD and resultant capillary leak $(13,55)$

Eosinophilia, often $>40 \%$, along with relatively normal percentages of lymphocytes and neutrophils, although mild to moderate increase in lymphocytes with reduced CD4:CD8 ratio may be seen $(6,7,56)$

Findings are nonspecific. Typically, there is increased cellularity in a mixed pattern with variable increases in lymphocytes, neutrophils, eosinophils, and foamy macrophages as well as occasional increases in plasma cells and mast cells $(57,58)$. Acute fulminant cases are often neutrophilic whereas more chronic cases tend to be lymphocytic (59). Classically, the CD4:CD8 ratio is reduced, but this finding is variable (60)

Increased cellularity along with increases in pigmented alveolar macrophages. An increase in eosinophils and increase in neutrophils may also be seen but lymphocyte levels tend to be low $(13,61,62)$

Lymphocytosis $>20 \%$ was seen among $85 \%$ of patients in a small case series (63). $50 \%$ of these cases have a low CD4:CD8 ratio

Forms of lung disease are associated with many systemic rheumatologic conditions; these have been loosely grouped together as IPAF or CT-ILD. Although findings are highly variable, increased lymphocytes are frequently reported (64). Among patients with dermatomyositis-associated ILD, lymphocytosis is often reported and more frequent in patients with MDA-5 antibody positivity $(65,66)$. Increases of neutrophils with rheumatoid arthritis and ILD are seen and increases in neutrophils and eosinophils can be seen in ILD associated with CREST syndrome $(67,68)$. Sjögren's syndrome associated ILD is also frequently associated with lymphocytosis; however, presence of neutrophils is associated with worsened disease (69). Scleroderma patients with ILD frequently have variable increases in neutrophils, eosinophils, or lymphocytes (70-72)

Lymphocytic interstitial pneumonia (LIP)

In one series of 15 patients, average lymphocyte counts were $30 \%(73)$. Within this series 11 were diagnosed with open lung biopsy, 3 with video-assisted thoracoscopic surgery, and 1 with transbronchial lung biopsy. Molecular testing for monoclonal gene rearrangements can confirm pulmonary lymphoma (74)

\section{Niemann-Pick disease}

Nonspecific interstitial pneumonia (NSIP)

Foamy histiocytes that are Periodic acid Schiff (PAS)-positive (75)

Typically a lymphocytosis, but highly variable $(76,77)$. There is reduced CD4:CD8 ratio, but cases of fibrotic NSIP often do not adhere to this pattern (78). Compared to UIP, NSIP typically have greater proportion of lymphocytes and similar or less percentage of neutrophils (79)

Pleuroparenchymal fibroelastosis (PPFE)

Respiratory bronchiolitis interstitial lung disease (RBILD)

Normal cell counts with slight lymphocyte elevation and low levels of neutrophils and eosinophils (80)

Identical to smokers; increased overall cellularity with heavy pigmented macrophage predominance $(13,81)$

Usual interstitial pneumonia (UIP), idiopathic pulmonary fibrosis

Increased total number of cells with a mixed pattern, often macrophage predominant with $<30 \%$ total lymphocytes, variable increases in neutrophils and small increase in eosinophils $(13,28,77,82)$. Although elevated BAL neutrophils can be associated with worsened survival, there is no consensus that BAL results portend prognosis (83) 
Table 6 Occupational \& environmental lung diseases

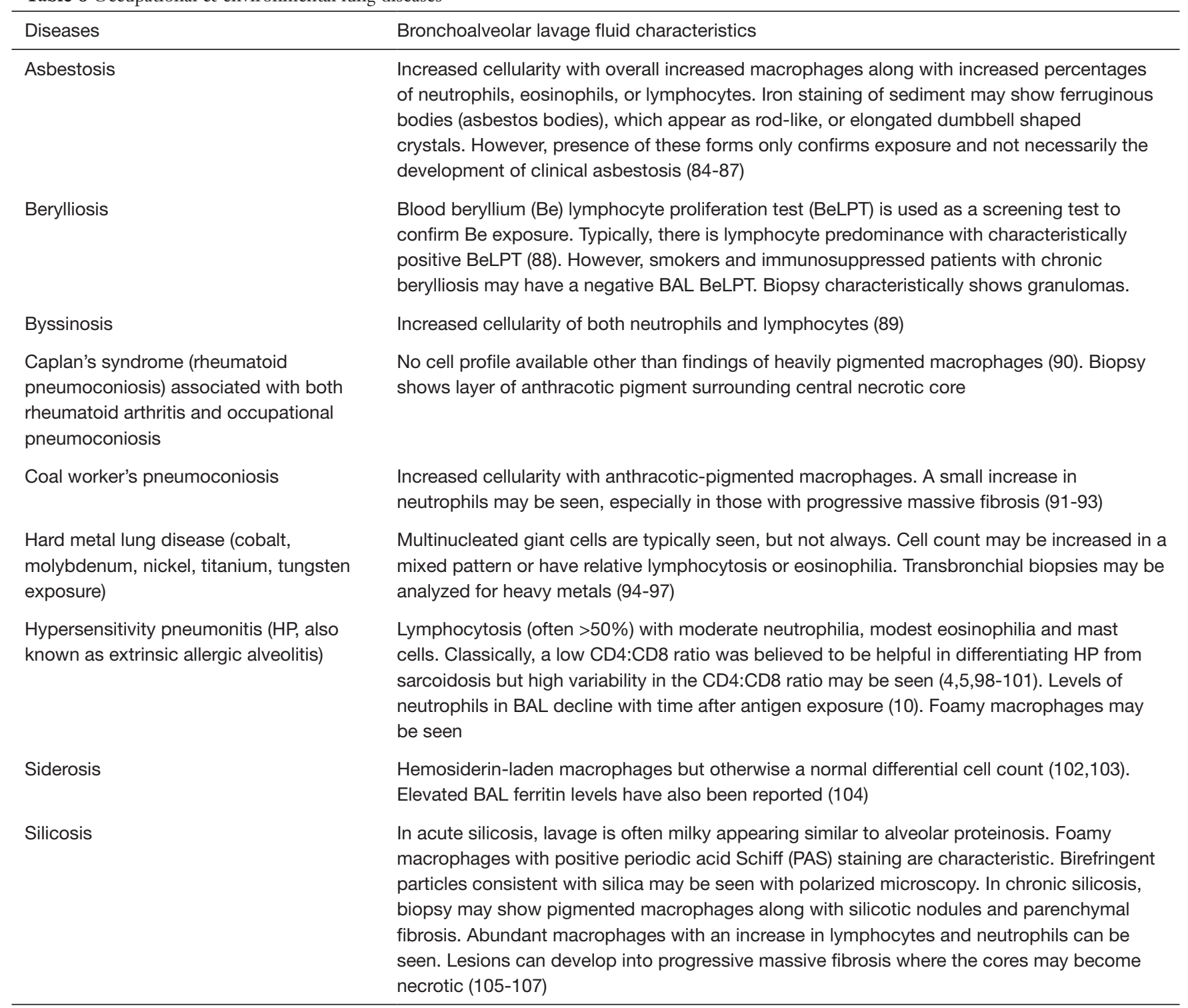

Table 7 Radiation-induced pneumonitis

\begin{tabular}{|c|c|}
\hline Diseases & Bronchoalveolar lavage fluid characteristics \\
\hline
\end{tabular}


Table 8 Infectious pneumonia: viruses

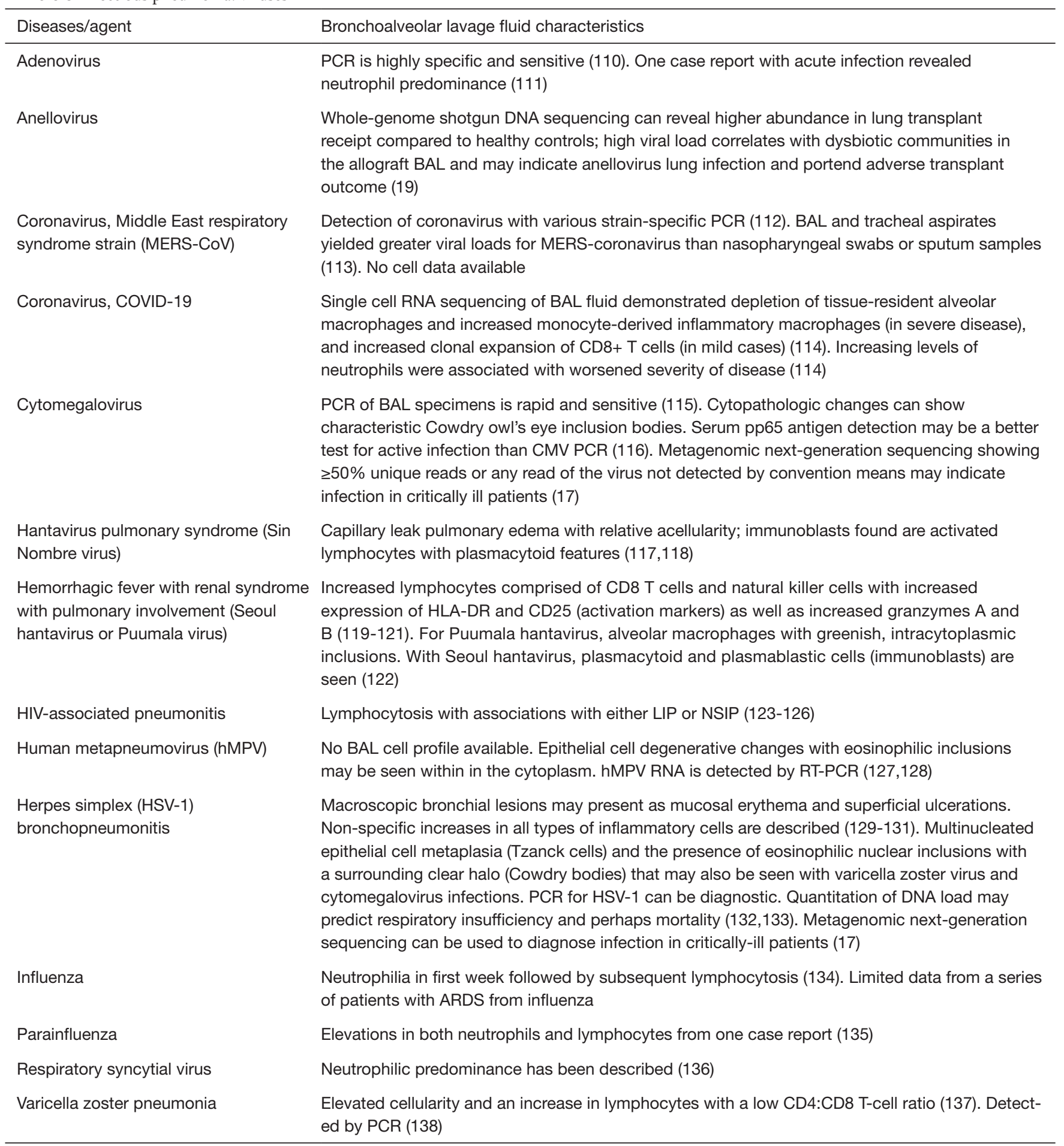


Table 9 Infectious pneumonia: bacteria

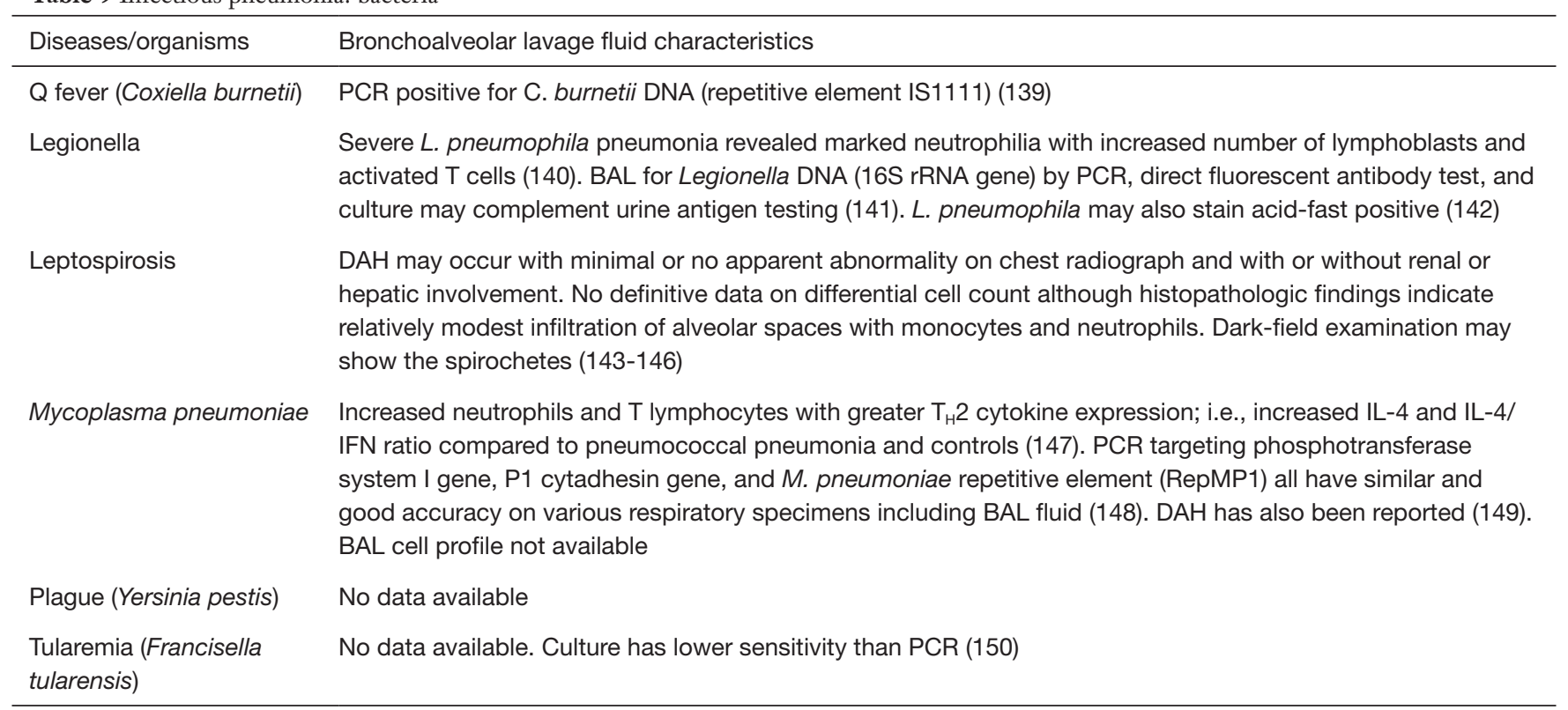

Table 10 Infectious pneumonia: fungi

\begin{tabular}{|c|c|}
\hline Diseases & Bronchoalveolar lavage fluid characteristics \\
\hline Blastomyces pneumonia & $\begin{array}{l}\text { Yeast forms are } \sim 8-15 \mu \mathrm{m} \text { in diameter with broad-based budding. Fungal culture adds to diagnostic yield of } \\
\text { cases not diagnosed on BAL cytopathology alone (153). Specific antigen testing in BAL fluid is only } 62.5 \% \\
\text { sensitive (154) }\end{array}$ \\
\hline Candida pneumonia & $\begin{array}{l}\text { Colonization frequency is quite high among critically ill and mechanically ventilated patients. No formal } \\
\text { quantitative thresholds exist to differentiate infection from colonization (155) }\end{array}$ \\
\hline Coccidioides pneumonia & $\begin{array}{l}\text { Coccidioides immitis spherules can be seen on Papanicolaou stain. Culture of BAL fluid has higher sensitivity } \\
\text { than microscopy alone (156). BAL cellular profiles tend to have elevations in neutrophils and may have very } \\
\text { mild elevations in eosinophils (157). Eosinophilia is more commonly seen in peripheral blood }\end{array}$ \\
\hline Histoplasma pneumonia & $\begin{array}{l}\text { Delicate smooth branching microconidia, } 2-3 \mu \mathrm{m} \text { in diameter with narrow-based budding can be seen on } \\
\text { microscopy. Histoplasma antigen enzyme immunoassay (EIA) in BAL fluid is quite sensitive (94\%) when tested } \\
\text { in a cohort of mostly immunocompromised patients (160) }\end{array}$ \\
\hline $\begin{array}{l}\text { Pneumocystis jirovecii } \\
\text { pneumonia (PJP) or PCP } \\
\text { pneumonia }\end{array}$ & $\begin{array}{l}\text { Cell count is nonspecific and may show relative increases in lymphocytes, neutrophils, and eosinophils. Foamy } \\
\text { alveolar casts and } P \text {. jirovecii clusters are seen on Giemsa stain. PCR and DFA can also be sent on BAL fluid } \\
\text { with improved yield in comparison to sputum alone (161-163) }\end{array}$ \\
\hline $\begin{array}{l}\text { Pulmonary mucor } \\
\text { (Zygomycosis) }\end{array}$ & $\begin{array}{l}\text { Ribbon-like fungal hyphae with non-septated, right-angle branching seen on Papanicolaou stains (164). In a } \\
\text { small case series, } 60 \% \text { of cases were diagnosed on BAL alone and the remaining } 40 \% \text { were diagnosed based } \\
\text { on transbronchial biopsy (165). Fungal stain on microscopy has higher yield than fungal culture }\end{array}$ \\
\hline
\end{tabular}


Table 11 Infectious pneumonia: parasites

\begin{tabular}{ll}
\hline Diseases & Bronchoalveolar lavage fluid characteristics \\
\hline $\begin{array}{l}\text { Angiostrongyliasis } \\
\text { Leishmaniasis }\end{array}$ & $\begin{array}{l}\text { Eosinophilia with nematode larvae on microscopy (166) } \\
\text { Paragonimiasis }\end{array}$ \\
$\begin{array}{l}\text { Ova \& parasite exam reveals ova which are golden yellow in color, } 80 \mu m \text { in length and } 40-50 \mu m \text { in diameter } \\
\text { with a flat operculum }(168,169)\end{array}$ \\
$\begin{array}{l}\text { Strongyloidiasis } \\
\text { Toxocariasis }\end{array}$ & Eosinophilia (172) \\
Toxoplasmosis & Trophozoites can be seen with Giemsa-stain (173)
\end{tabular}

Table 12 Infectious pneumonia: mycobacteria

\begin{tabular}{|c|c|}
\hline Diseases & Bronchoalveolar lavage fluid characteristics \\
\hline $\begin{array}{l}\text { Non-tuberculous } \\
\text { mycobacteria (NTM) }\end{array}$ & $\begin{array}{l}\text { Acid-fast bacilli on Ziehl-Neelsen stain may be seen but unusual unless mycobacterial burden is high. A single } \\
\text { case report in a patient with Hodgkin's lymphoma and Mycobacterium mucogenicum had a lymphocyte } \\
\text { predominance (177). NTM lung disease is typically associated with increased percentage of lymphocytes and } \\
\text { neutrophils (178). With Mycobacterium avium complex (MAC)-associated nodular bronchiectasis, those who } \\
\text { were "not deteriorating" ( } n=8 \text { ) had increased lymphocyte and neutrophils but macrophages > lymphocytes }> \\
\text { neutrophils; in contrast, of those who were "deteriorating" ( } n=13 \text { ), the relative percentages were neutrophils } \\
\geq \text { macrophages > lymphocytes (179). In } 37 \text { MAC lung disease subjects, those with neutrophil-dominant BAL } \\
\text { had more severe radiographic disease and greater clinical deterioration than those with lymphocyte-dominant } \\
\text { BAL (180) }\end{array}$ \\
\hline
\end{tabular}

Table 13 Drug-induced pneumonitis

\begin{tabular}{ll}
\hline Drugs & Bronchoalveolar lavage fluid characteristics \\
\hline $\begin{array}{l}\text { Adalimumab (anti-TNF } \\
\text { monoclonal antibody) }\end{array}$ & $\begin{array}{l}\text { Macrophage predominance with slight elevations in eosinophils and lymphocytes (181). Transbronchial biopsy } \\
\text { with thickening in alveolar septa and mild to moderate lymphocytic interstitial cellularity consistent with ILD } \\
\text { and OP }\end{array}$ \\
$\begin{array}{l}\text { Alemtuzumab (anti-CD52 } \\
\text { monoclonal antibody) }\end{array}$ & $\begin{array}{l}\text { Associated with DAH and interstitial pneumonitis (182). No BAL cell profile available } \\
\text { Amiodarone }\end{array}$ \\
& $\begin{array}{l}\text { Highly variable pattern: normal to increased levels of lymphocytes, neutrophils, and eosinophils. } \\
\text { Lymphocytosis and foamy intracytoplasmic vacuoles in alveolar macrophages (due to accumulation of } \\
\text { phospholipids) may indicate only exposure and not necessarily toxicity (183-186). On electron microscopy, } \\
\text { the foamy cytoplasmic vacuoles correspond to surfactant-like lamellar bodies. Cellular differential is not } \\
\text { prognostic of outcome } \\
\text { Hypersensitivity pneumonitis with BAL showing predominance of lymphocytes as well as fibrotic changes are } \\
\text { reported (187) } \\
\text { Rare association with usual interstitial pneumonitis, organizing pneumonia or DAD (188). No BAL cell profile } \\
\text { available }\end{array}$ \\
&
\end{tabular}

Table 13 (continued) 
Table 13 (continued)

\begin{tabular}{|c|c|}
\hline Drugs & Bronchoalveolar lavage fluid characteristics \\
\hline $\begin{array}{l}\text { Bortezomib (proteasome } \\
\text { inhibitor) }\end{array}$ & $\begin{array}{l}\text { Associated with a pattern of organizing pneumonia, bronchiolitis obliterans, pleural effusions, or } \\
\text { DAD (192-194). No BAL cell profile available }\end{array}$ \\
\hline $\begin{array}{l}\text { Busulfan (alkylating } \\
\text { chemotherapeutic) }\end{array}$ & Both increases in lymphocytes or neutrophils have been reported along with atypia in type I pneumocytes (196) \\
\hline Captopril and perindopril & $\begin{array}{l}\text { Rarely, diffuse interstitial/alveolar pneumonitis has been reported which may have lymphocytic infiltration or } \\
\text { eosinophilic pneumonia }(197,198)\end{array}$ \\
\hline $\begin{array}{l}\text { Cetuximab (anti-EGFR } \\
\text { monoclonal antibody) }\end{array}$ & $\begin{array}{l}\text { Associated with infusion-related bronchospasm, pneumonitis, bronchiolitis, organizing pneumonia and } \\
\text { pulmonary fibrosis }(201,202) \text {. Pneumonitis was more common in patients also receiving radiation therapy for } \\
\text { non-small cell lung cancer (203). No BAL cell profile available }\end{array}$ \\
\hline $\begin{array}{l}\text { Checkpoint inhibitors (anti- } \\
\text { PD-1, anti-CTLA-4, anti- } \\
\text { PD-L1) }\end{array}$ & $\begin{array}{l}\text { Risk of checkpoint inhibitor pneumonitis (CIP)-consolidation, organizing pneumonia, GGO, interlobular } \\
\text { septal thickening, and traction bronchiectasis - greater with anti-PD-1 and anti-PD-L1 than anti-CTLA4. In a } \\
\text { meta-analysis of nearly } 4,500 \text { patients on anti-PD-1 inhibitor, the overall incidence of pneumonitis was } 2.7 \% \\
\text { and the pneumonitis was more frequent and severe in patients with lung cancer or renal cell carcinoma than } \\
\text { melanoma (204,205). In } 22 \text { patients with CIP, the mean BAL lymphocyte count was } 14 \% \text { (range 4-90\%) (206). } \\
\text { Another study of } 30 \text { patients with CIP determined the mean BAL lymphocytes to be } 34 \%(1-70 \%)(207) \text {. } \\
\text { High-grade CIP is associated with poor prognosis (208) }\end{array}$ \\
\hline $\begin{array}{l}\text { Dasatinib } \\
\text { (Tyrosine kinase inhibitor) }\end{array}$ & $\begin{array}{l}\text { Pneumonitis with lymphocytosis is most commonly reported (213). Also associated with lymphocytic, typically } \\
\text { exudative pleural effusions. Another single report with BAL neutrophilia was also reported }(214)\end{array}$ \\
\hline $\begin{array}{l}\text { Docetaxel (anti-mitotic } \\
\text { chemotherapeutic) }\end{array}$ & $\begin{array}{l}\text { Associated with a capillary leak syndrome } 8-14 \text { days after administration }(215,216) \text {. No BAL cell profile } \\
\text { available }\end{array}$ \\
\hline $\begin{array}{l}\text { Doxorubicin } \\
\text { (topoisomerase inhibitor) }\end{array}$ & Possible association with organizing pneumonia from limited data (217). Associated with radiation recall effect \\
\hline $\begin{array}{l}\text { Erlotinib (tyrosine kinase } \\
\text { inhibitor) }\end{array}$ & $\begin{array}{l}\text { Associated with acute development of ILD with either a DAD or OP pattern (218-220). BAL with neutrophilic } \\
\text { predominance }\end{array}$ \\
\hline $\begin{array}{l}\text { Etanercept (soluble p75 } \\
\text { TNF receptor subunit) }\end{array}$ & $\begin{array}{l}\text { Associated with development of granulomatous inflammation and a sarcoidosis-like reaction or organizing } \\
\text { pneumonia with lymphocytic BAL }(221-223)\end{array}$ \\
\hline
\end{tabular}

Table 13 (continued) 
Table 13 (continued)

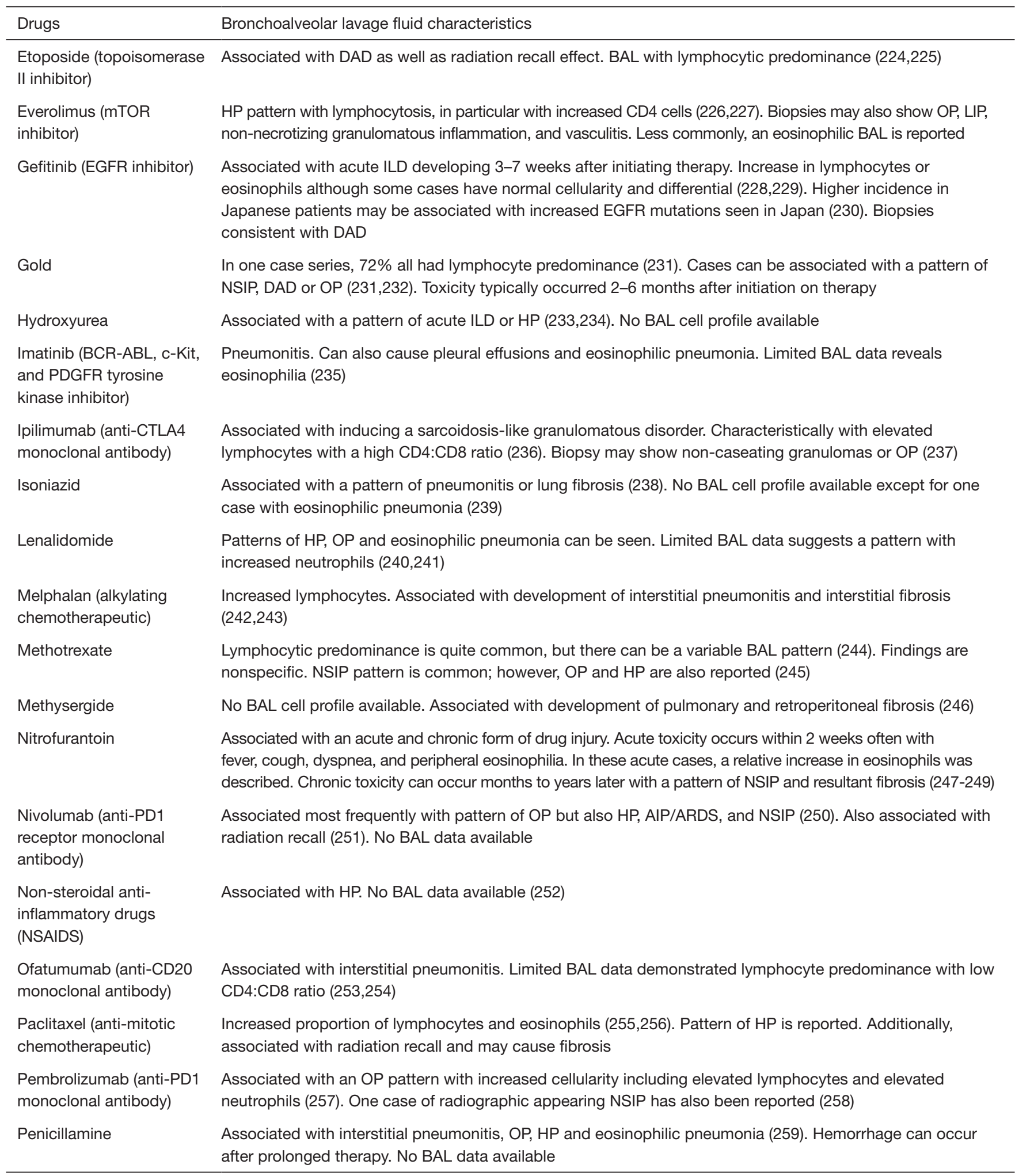

Table 13 (continued) 
Table 13 (continued)

\begin{tabular}{|c|c|}
\hline Drugs & Bronchoalveolar lavage fluid characteristics \\
\hline Propylthiouracil & Associated with ANCA positive vasculitis, capillaritis, and DAD (262) \\
\hline $\begin{array}{l}\text { Rituximab (anti-CD20 } \\
\text { monoclonal antibody) }\end{array}$ & $\begin{array}{l}\text { Interstitial pneumonitis, OP and ARDS are all reported. Limited BAL data suggest lymphocytosis is a common } \\
\text { feature (263-265) }\end{array}$ \\
\hline Sulfasalazine & Eosinophilic pneumonia, HP and OP patterns have been described (269-271) \\
\hline $\begin{array}{l}\text { Sunitinib (tyrosine kinase } \\
\text { inhibitor which blocks } \\
\text { receptors for PDGFR and } \\
\text { VEGFR) }\end{array}$ & Associated with recall pneumonitis and increased risk of pulmonary embolism (272). No BAL data available \\
\hline Valproic acid & $\begin{array}{l}\text { Neutrophil predominance (274). Valproic acid can also be associated with an eosinophilic pleural effusion or } \\
\text { DAH }(275,276)\end{array}$ \\
\hline
\end{tabular}

Table 14 Miscellaneous lung diseases

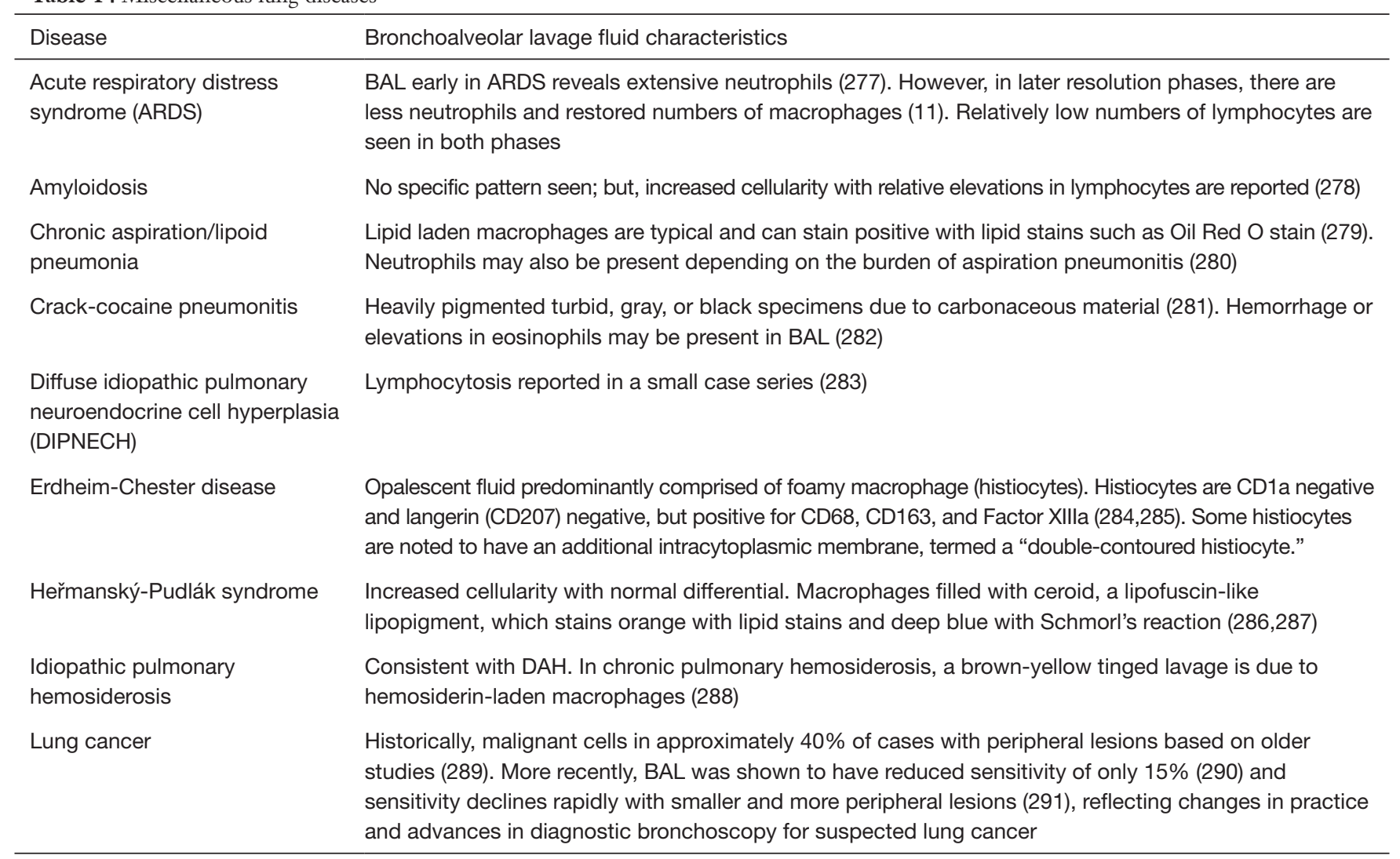

Table 14 (continued) 
Table 14 (continued)

\begin{tabular}{|c|c|}
\hline Disease & Bronchoalveolar lavage fluid characteristics \\
\hline $\begin{array}{l}\text { Pulmonary alveolar proteinosis } \\
\text { (PAP) }\end{array}$ & $\begin{array}{l}\text { Diagnostic in close to } 100 \% \text { of the cases. Fluid appears milky and if left standing, settles into a } \\
\text { layer of lipoproteinaceous sediment. No particular cellular pattern on BAL is helpful for diagnosis } \\
\text { although elevated lymphocytes or eosinophils have been reported }(183,294) \text {. Cytology reveals foamy } \\
\text { macrophages and globules that are PAS-positive for lipoproteinaceous material (295-298) }\end{array}$ \\
\hline $\begin{array}{l}\text { Pulmonary capillary } \\
\text { hemangiomatosis }\end{array}$ & $\begin{array}{l}\text { DAH with hemosiderin-laden macrophages (299). Transbronchial biopsy should be avoided given risk } \\
\text { for hemorrhage }\end{array}$ \\
\hline $\begin{array}{l}\text { Pulmonary post-transplant } \\
\text { lymphoproliferative disorder } \\
\text { (PTLD), with spectrum ranging } \\
\text { from polyclonal lymphoid } \\
\text { hyperplasia to lymphoma with a } \\
\text { variety of imaging findings }\end{array}$ & $\begin{array}{l}\text { Typically, lymphocytic predominant that may be polyclonal or clonal B cells that are Epstein-Barr virus } \\
\text { (EBV) positive by PCR. Screening for PTLD has been recommended by assaying for EBV by PCR in the } \\
\text { blood or in the BAL }(300,301)\end{array}$ \\
\hline $\begin{array}{l}\text { Pulmonary veno-occlusive } \\
\text { disease }\end{array}$ & $\begin{array}{l}\text { DAH with hemosiderin-laden macrophages }(302,303) \text {. Bronchoscopic appearance of intensely } \\
\text { hyperemic lobar and segmental bronchi with longitudinal streaking has been reported. Transbronchial } \\
\text { biopsy should be avoided given risk for hemorrhage }(304)\end{array}$ \\
\hline Sarcoidosis & $\begin{array}{l}\text { Majority of cases }(90 \%) \text { demonstrate increased lymphocytes with normal levels of neutrophils and } \\
\text { eosinophils }(3,5) \text {. Classically, } C D 4: C D 8 \text { ratio } \geq 2 \text {, but this ratio can be variable including cases with CD8 } \\
\text { predominance (305). A combination of CD4:CD8 ratio } \geq 2, \leq 1 \% \text { neutrophils, and } \leq 1 \% \text { eosinophils has a } \\
\text { similar specificity and positive predictive value as multiple non-caseating granulomas on transbronchial } \\
\text { biopsy in distinguishing sarcoidosis from non-sarcoidosis disease (306). BAL CD4:CD8 ratio does not } \\
\text { predict prognosis or response to treatment }\end{array}$ \\
\hline $\begin{array}{l}\text { Electronic cigarette/vaping- } \\
\text { associated lung injury (EVALI) }\end{array}$ & $\begin{array}{l}\text { Majority of cases are linked with the use of marijuana oils or concentrates, associated with the presence } \\
\text { of medium chain triglyceride, vitamin E acetate, and other lipids in the inhaled product (307-311). Lung } \\
\text { diseases described with EVALI include DAD, AEP, OP, lipoid pneumonia, and HP and may present on } \\
\text { chest CT as consolidation, GGO, and peripheral reticulations. In case series, BAL showed moderate } \\
\text { increase in neutrophils (20-50\%), mild increase in lymphocytes }(0-25 \%) \text {, and high numbers of lipid- } \\
\text { laden (Oil Red O stain positive) macrophages (25-75\%) (312-314) }\end{array}$ \\
\hline
\end{tabular}

Table 15 Diseases characterized by particular BAL cell differential

\begin{tabular}{lll}
\hline Eosinophilic-dominant & Lymphocytic-dominant & Neutrophilic-dominant \\
\hline Diseases: acute eosinophilic & Diseases: berylliosis, cryoglobulinemia, granulomatous & Diseases: acute interstitial \\
pneumonia, allergic & lymphocytic interstitial lung disease, HIV-associated & pneumonia, ARDS, initial phase, \\
bronchopulmonary aspergillosis, & pneumonitis, hypersensitivity pneumonitis, lymphocytic & bacterial pneumonia, cystic fibrosis, \\
chronic eosinophilic pneumonia, & interstitial pneumonia, non-specific interstitial pneumonia, & granulomatous polyangiitis. Drug- \\
eosinophilic granulomatosis with & sarcoidosis, tuberculosis. Drug-induced: checkpoint & induced: bleomycin, erlotinib, \\
polyangiitis, parasitic pneumonias. & inhibitors (anti-PD-1 \& anti-PD-L1 > anti-CTLA-4), dasatinib, & trastuzumab, valproic acid \\
Drug-induced: carbamazepine, & etanercept, etoposide, everolimus, gold, pembrolizumab, & \\
sulfasalazine, others & radiation-induced pneumonitis, sirolimus & \\
\hline
\end{tabular}

BAL, bronchoalveolar lavage. 
Table 16 Diffuse alveolar hemorrhage

Diffuse alveolar hemorrhage due to non-infectious causes

DAH with pulmonary capillaritis

Isolated pauci-immune necrotizing pulmonary capillaritis

Granulomatous polyangiitis

Microscopic polyangiitis

Mixed cryoglobulinemia

Behcet's syndrome

Henoch-Schönlein purpura

Goodpasture's syndrome*

Pauci-immune glomerulonephritis

Immune-complex-associated glomerulonephritis

Collagen-vascular disease (systemic lupus erythematosus ${ }^{*}$, polymyositis, rheumatoid arthritis, mixed-connective tissue disease, scleroderma)

Primary antiphospholipid antibody syndrome

Acute lung transplant rejection

Autologous bone marrow transplantation

Drugs (e.g., propylthiouracil with positive anti-neutrophilic cytoplasmic antibody)

DAH without capillaritis

Idiopathic pulmonary hemosiderosis

Systemic lupus erythematosus*

Goodpasture's syndrome*

Diffuse alveolar damage-e.g., after cytotoxic drug preconditioning therapy for bone marrow transplantation

Penicillamine-bland hemorrhage; uncommon; occurs after 1 year of therapy

Tuberous sclerosis

Trimellitic anhydride

Mitral stenosis

Coagulation disorders

Pulmonary veno-occlusive disease

Pulmonary capillary hemangiomatosis

Lymphangioleiomyomatosis - due to rupture of postcapillary venules, which are infiltrated by smooth muscles

Pulmonary embolism with infarction

Diffuse alveolar hemorrhage due to infectious causes (315)

Immunocompromised patients

Adenovirus

Cytomegalovirus

Invasive aspergillosis

Legionella

Table 16 (continued) 
Table 16 (continued)

Mycoplasma pneumoniae
Strongyloides
Immunocompetent patients
Dengue
Hantavirus
Influenza A (H1N1)
Leptospirosis
Malaria
Staphylococcus aureus

*, capillaritis may or may not be present. BAL typically shows bloody or pink to orange-brown color and hemosiderin-laden macrophages (which appear after 48 hours of bleeding) with intensity of the iron staining correlating well with histologic severity of DAH.

Table 17 Diseases with foamy alveolar macrophages

\begin{tabular}{|c|c|}
\hline Diseases & Comments \\
\hline Amiodarone & $\begin{array}{l}\text { Amiodarone interferes with the movement of phospholipids across intracellular membranes and inhibits } \\
\text { phospholipid catabolism via inhibition of lysosomal phospholipase } 2 \text {. Thus, in alveolar macrophages the } \\
\text { accumulation of phospholipids as foamy vacuoles stain positive with Oil Red O }\end{array}$ \\
\hline Erdheim-Chester disease & $\begin{array}{l}\text { CD68 positive (and CD1a and S100 negative) foamy macrophages (considered to contain some form of } \\
\text { lipid) although the precise cause of the accumulation is not known ( } 317)\end{array}$ \\
\hline Hypersensitivity pneumonitis & Lymphocytic dominant background with foamy macrophages (318) \\
\hline Pulmonary alveolar proteinosis & $\begin{array}{l}\text { Large foamy macrophages due to accumulation of lipoproteinaceous sediment. The vacuoles stain for } \\
\text { both lipids (Oil Red O) and polysaccharides (PAS stain) because lipids, polysaccharides, and glycolipids } \\
\text { associate with surfactant proteins. With GM-CSF treatment, intracellular debris and extracellular } \\
\text { lipoproteinacious material may resolve but foamy macrophages containing ingested lipoproteinacious } \\
\text { material may remain (298). However, clinical efficacy of GM-CSF treatment is not universally proven (319) }\end{array}$ \\
\hline $\begin{array}{l}\text { Electronic cigarette/vaping- } \\
\text { associated lung injury }\end{array}$ & Due to an acute lung injury associated with vitamin $\mathrm{E}$ acetate and other additives in the inhaled product \\
\hline \multicolumn{2}{|c|}{$\begin{array}{l}\text { The description of "foamy macrophages" refers to the multiple, relatively large vacuoles present in the cytoplasm of BAL cells, most } \\
\text { often the alveolar macrophages. A stain may be a "negative stain" in that it stains the structures outside of the vacuoles that comprise } \\
\text { the intracellular "foamy" characteristics (Figure 1A,B). Since the content of the foamy vacuoles are often lipid or lipoproteinaceous } \\
\text { material, the content of the vacuoles may be stained positively with Oil Red O (Figure } 1 C \text { ). Peridic acid-Schiff (PAS) stains structures } \\
\text { outside of the vacuoles but may also stain the contents within the vacuoles if they contain glycoproteins and glycolipids since PAS stains } \\
\text { polysaccharides. }\end{array}$} \\
\hline
\end{tabular}
of dying macrophages that have ingested silica and of damaged epithelial cells (316). Birefringent silica particles may be present phospholipid catabolism via inhibition of lysosomal phospholipase 2. Thus, in alveolar macrophages the (ceumulation of phospholipids as foamy vacuoles stain positive with Oil Red

Chronic aspiration and lipoid pneumonia

Erdheim-Chester disease

Hypersensitivity pneumonitis stain positive with Oil Red O; the sphingomyelin stain weakly positive with PAS although this may be both lipids (Oil Red O) and polysaccharides (PAS stain) because lipids, polysaccharides, and glycolipids

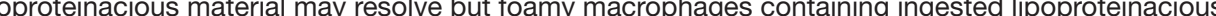
associated lung injury

CD68 positive (and CD1a and S100 negative) foamy macrophages (considered to contain some form of 

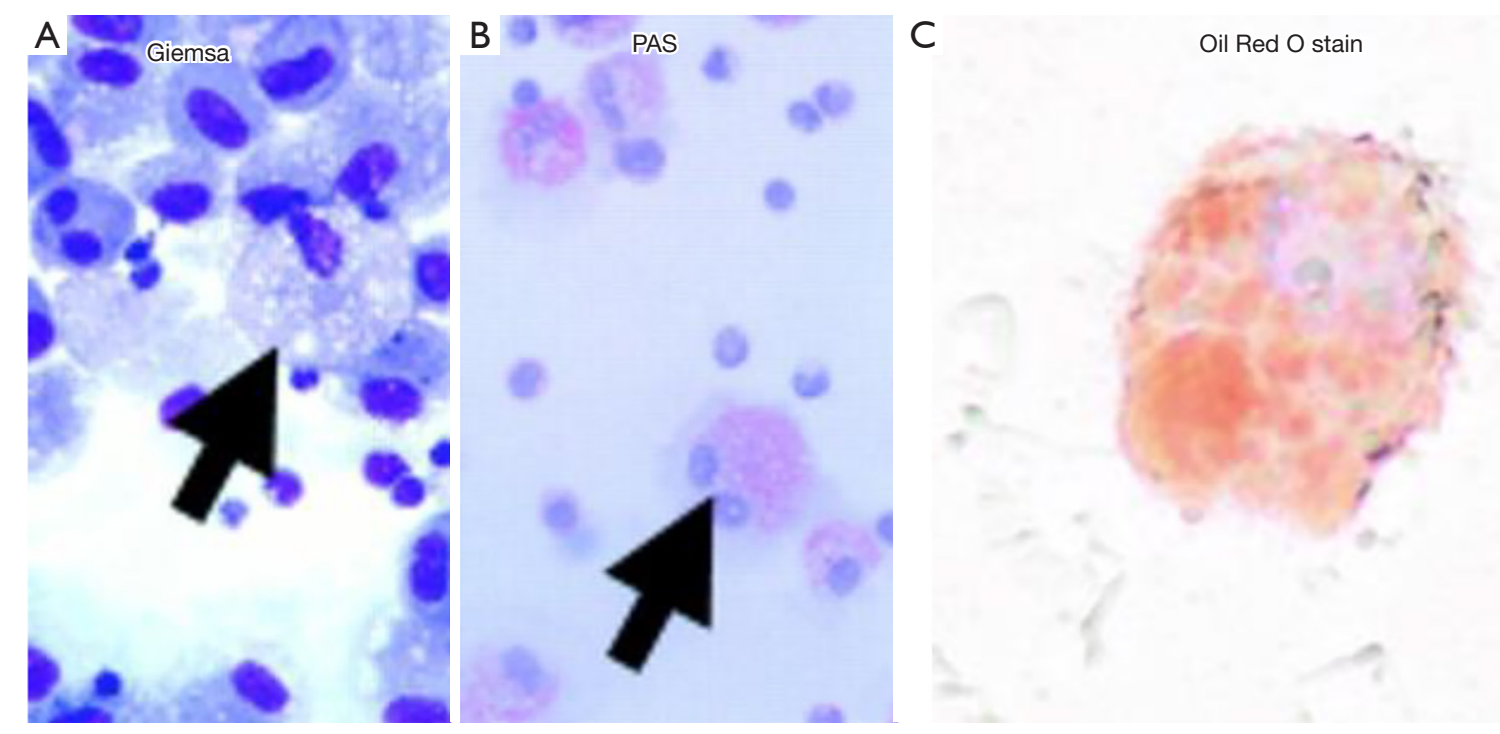

Figure 1 Visual detection of foamy macrophages. (A) Giemsa stain and (B) Periodic acid-Schiff (PAS) stain of BAL from a patient with pulmonary alveolar proteinosis demonstrating the "ghosts" of the foamy vacuoles [Figure modified from (298)]. A Wright-Giemsa stain is also a "negative stain" and will also accomplish the same visual effect. (C) Oil Red O stain of the BAL from a patient with electronic cigarette/vaping-associated lung injury (EVALI) showing lipid-filled vacuoles within an alveolar macrophage. Magnification: 1,000x. BAL, bronchoalveolar lavage.

with kerosene aspiration (322) utilizing low volume segmental lavage with good radiographic resolution. In children with refractory Mycoplasma pneumoniae pneumonia complicated by atelectasis, therapeutic BAL was shown to significantly shorten the duration of illness, time to radiographic resolution, and length of hospital stay (323).

\section{Conclusions}

Since the first bronchial irrigation by Stitt in 1927, BAL has evolved to become an often-used diagnostic procedure throughout most of the world. With development of additional assays for microbial product (e.g., galactomannan for invasive fungal disease), immunostaining for organisms (e.g., direct fluorescent antibody for pneumocystis), and nucleic acid amplification tests for specific microbes, BAL for diagnosis of infectious disorders has made significant progress and will continue to advance further with new technologies. While differential cell count profiles and ancillary testing on BAL fluid may in themselves not be specific or diagnostic, in the proper clinical context, the BAL findings may be the deciding factor in making a confident diagnosis. For example, in a patient with home bird exposure, significant lymphocytosis on BAL and consistent imaging, a confident diagnosis of hypersensitivity pneumonitis can be made even in the absence of lung biopsy. Even when BAL results are non-diagnostic, their findings may help narrow the differential diagnosis. This review summarizes the vast array of additional characteristics and specific signature findings that can be a helpful aid to diagnosis. Herein, we present a current, succinct compilation of BAL data in a wide range of lung disease. In addition, we also listed those diseases and drug toxicities for which specific BAL data have not been reported.

In the future, it is likely that additional targeted diagnostics such as MALDI-TOF and PCR ES-M on BAL fluid will facilitate more rapid diagnosis of infectious pneumonia. Of particular interest is not only the ability to determine the etiology of infection but also to identify drug-resistant microbes. Such advances would transform the care of septic patients and also improve adherence to antibiotic stewardship. Additionally, genomic testing of BAL fluid may help clinicians differentiate patients with IPF from other forms of ILD as well as stratify patients with lung nodules into different risk groups for lung cancer. While surgical lung biopsy remains the gold standard for the diagnosis of various lung diseases, less 
Table 18 Diagnostic or highly suggestive BAL cellular phenotypes

\begin{tabular}{|c|c|}
\hline Diseases & Key BAL fluid findings and other clinical supporting features \\
\hline Berylliosis & Positive BeLPT with known or suspected beryllium exposure and compatible chest imaging \\
\hline Hard metal lung disease & Multinucleated giant cells with known or suspected exposure and compatible chest imaging \\
\hline Heřmanský-Pudlák syndrome & $\begin{array}{l}\text { Alveolar macrophages may show yellow-brown staining of ceroid accumulation; the ceroid } \\
\text { material may stain weakly acid-fast positive }\end{array}$ \\
\hline Pulmonary alveolar microlithiasis & Presence of microliths \\
\hline Pulmonary alveolar proteinosis & $\begin{array}{l}\text { Presence of milky and turbid appearance with a thick settling layer of sediment due to the } \\
\text { lipoproteinaceous deposits }\end{array}$ \\
\hline Pulmonary Langerhans cell histiocytosis & $\begin{array}{l}\geq 5 \% \text { of cells positive for CD1a. S- } 100 \text { positivity is supportive but less specific. Chest imaging } \\
\text { shows cysts and nodules in an upper zone distribution in earlier phase and predominantly } \\
\text { cysts in end-stage disease }\end{array}$ \\
\hline
\end{tabular}

BAL, bronchoalveolar lavage; AEP, acute eosinophilic pneumonia; AIP, acute interstitial pneumonitis; ANCA, antineutrophil cytoplasmic antibodies; ARDS, acute respiratory distress syndrome; BAL, bronchoalveolar lavage; COPD, chronic obstructive pulmonary disease; CTLA-4, cytotoxic T-lymphocyte-associated protein 4; DAD, diffuse alveolar damage; DAH, diffuse alveolar hemorrhage; EGFR, epidermal growth factor receptor; GGO, ground glass opacities; HP, hypersensitivity pneumonitis; ILD, interstitial lung disease; LIP, lymphocytic interstitial pneumonitis; NSIP, non-specific interstitial pneumonitis; OP, organizing pneumonia; PAS, periodic acid-Schiff; PD1, programmed cell death protein-1; PD-L1, programmed cell death ligand 1; PDGFR, platelet-derived growth factor receptor; PLCH, pulmonary Langerhans cell histiocytosis; VEGF, vascular endothelial growth factor.

invasive diagnostic techniques will become adopted if their yield becomes significantly more accurate. The ultimate goal would be to advance diagnostic techniques on BAL fluid to rival the sensitivity and specificity of the current gold standard of lung biopsy.

\section{Acknowledgments}

Funding: None.

\section{Footnote}

Conflicts of Interest: All authors have completed the ICMJE uniform disclosure form (available at http://dx.doi. org/10.21037/jtd-20-651). EDC serves as an unpaid editorial board member of fournal of Thoracic Disease. The other author has no conflicts of interest to declare.

Ethical Statement: The authors are accountable for all aspects of the work in ensuring that questions related 
to the accuracy or integrity of any part of the work are appropriately investigated and resolved.

Open Access Statement: This is an Open Access article distributed in accordance with the Creative Commons Attribution-NonCommercial-NoDerivs 4.0 International License (CC BY-NC-ND 4.0), which permits the noncommercial replication and distribution of the article with the strict proviso that no changes or edits are made and the original work is properly cited (including links to both the formal publication through the relevant DOI and the license). See: https://creativecommons.org/licenses/by-nc-nd/4.0/.

\section{References}

1. Stitt HL. Bronchial aspiration and irrigation with a hypertonic solution. J Med 1927;5:112-7.

2. Ahmad M, Livingston DR, Golish JA, et al. The safety of outpatient transbronchial biopsy. Chest 1986;90:403-5.

3. Drent M, Mansour K, Linssen C. Bronchoalveolar lavage in sarcoidosis. Semin Respir Crit Care Med 2007;28:486-95.

4. Semenzato G, Bjermer L, Costabel U, et al. Clinical guidelines and indications for bronchoalveolar lavage (BAL): extrinsic allergic alveolitis. Eur Respir J 1990;3:9456, 961-9.

5. Welker L, Jorres RA, Costabel U, et al. Predictive value of BAL cell differentials in the diagnosis of interstitial lung diseases. Eur Respir J 2004;24:1000-6.

6. Sohn JW. Acute eosinophilic pneumonia. Tuberc Respir Dis (Seoul) 2013;74:51-5.

7. Costabel U, Guzman J, Bonella F, et al. Bronchoalveolar lavage in other interstitial lung diseases. Semin Respir Crit Care Med 2007;28:514-24.

8. O'Donnell R, Breen D, Wilson S, et al. Inflammatory cells in the airways in COPD. Thorax 2006;61:448-54.

9. Smith DL, Deshazo RD. Bronchoalveolar lavage in asthma. An update and perspective. Am Rev Respir Dis 1993;148:523-32.

10. Fournier E, Tonnel AB, Gosset P, et al. Early neutrophil alveolitis after antigen inhalation in hypersensitivity pneumonitis. Chest 1985;88:563-6.

11. Nakos G, Kitsiouli EI, Tsangaris I, et al. Bronchoalveolar lavage fluid characteristics of early intermediate and late phases of ARDS. Alterations in leukocytes, proteins, PAF and surfactant components. Intensive Care Med 1998;24:296-303.

12. Raghu G, Collard HR, Egan JJ, et al. An official ATS/ ERS/JRS/ALAT statement: idiopathic pulmonary fibrosis: evidence-based guidelines for diagnosis and management. Am J Respir Crit Care Med 2011;183:788-824.

13. Meyer KC, Raghu G, Baughman RP, et al. An official American Thoracic Society clinical practice guideline: the clinical utility of bronchoalveolar lavage cellular analysis in interstitial lung disease. Am J Respir Crit Care Med 2012;185:1004-14.

14. Kim ES, Kim EC, Lee SM, et al. Bacterial yield from quantitative cultures of bronchoalveolar lavage fluid in patients with pneumonia on antimicrobial therapy. Korean J Intern Med 2012;27:156-62.

15. Mok JH, Eom JS, Jo EJ, et al. Clinical utility of rapid pathogen identification using matrix-assisted laser desorption/ionization time-of-flight mass spectrometry in ventilated patients with pneumonia: A pilot study. Respirology 2016;21:321-8.

16. Ullberg M, Luthje P, Molling P, et al. BroadRange Detection of Microorganisms Directly from Bronchoalveolar Lavage Specimens by PCR/ Electrospray Ionization-Mass Spectrometry. PLoS One 2017;12:e0170033.

17. Li Y, Sun B, Tang X, et al. Application of metagenomic next-generation sequencing for bronchoalveolar lavage diagnostics in critically ill patients. Eur J Clin Microbiol Infect Dis 2020;39:369-74.

18. Pendleton KM, Erb-Downward JR, Bao Y, et al. Rapid Pathogen Identification in Bacterial Pneumonia Using Real-Time Metagenomics. Am J Respir Crit Care Med 2017;196:1610-2.

19. Young JC, Chehoud C, Bittinger K, et al. Viral metagenomics reveal blooms of anelloviruses in the respiratory tract of lung transplant recipients. Am J Transplant 2015;15:200-9.

20. Schneeberger PHH, Prescod J, Levy L, et al. Microbiota analysis optimization for human bronchoalveolar lavage fluid. Microbiome 2019;7:141.

21. Stanzel F. Bronchoalveolar lavage. In: Ernst A, Herth FJF. editors. Principles and Practice of Interventional Pulmonology. New York: Springer Science + Business Media, 2012:165-76.

22. Klech H, Pohl W. Technical Recommendations and Guidelines for Bronchoalveolar Lavage (BAL). Report of the European Society of Pneumonology Task Group. Eur Respir J 1989;2:561-85.

23. Du Rand IA, Blaikley J, Booton R, et al. British Thoracic Society guideline for diagnostic flexible bronchoscopy in adults: accredited by NICE. Thorax 2013;68 Suppl 1:i1-i44.

24. Dransfield MT, Garver RI, Weill D. Standardized 
guidelines for surveillance bronchoscopy reduce complications in lung transplant recipients. J Heart Lung Transplant 2004;23:110-4.

25. Hodge SJ, Hodge GL, Holmes M, et al. Flow cytometric characterization of cell populations in bronchoalveolar lavage and bronchial brushings from patients with chronic obstructive pulmonary disease. Cytometry B Clin Cytom 2004;61:27-34.

26. Conte BA, Laforet EG. The role of the topical anesthetic agent in modifying bacteriologic data obtained by bronchoscopy. N Engl J Med 1962;267:957-60.

27. Strange C, Barbarash RA, Heffner JE. Lidocaine concentrations in bronchoscopic specimens. Chest 1988;93:547-9.

28. Bronchoalveolar lavage constituents in healthy individuals, idiopathic pulmonary fibrosis, and selected comparison groups. The BAL Cooperative Group Steering Committee. Am Rev Respir Dis 1990;141:S169-202.

29. Heron M, Grutters JC, ten Dam-Molenkamp KM, et al. Bronchoalveolar lavage cell pattern from healthy human lung. Clin Exp Immunol 2012;167:523-31.

30. Jouneau S, Poineuf JS, Minjolle S, et al. Which patients should be tested for viruses on bronchoalveolar lavage fluid? Eur J Clin Microbiol Infect Dis 2013;32:671-7.

31. Karimi R, Tornling G, Grunewald J, et al. Cell recovery in bronchoalveolar lavage fluid in smokers is dependent on cumulative smoking history. PLoS One 2012;7:e34232.

32. Greenberger PA, Smith LJ, Hsu CC, et al. Analysis of bronchoalveolar lavage in allergic bronchopulmonary aspergillosis: divergent responses of antigen-specific antibodies and total $\mathrm{IgE}$. J Allergy Clin Immunol 1988;82:164-70.

33. Kono Y, Tsushima K, Yamaguchi K, et al. The utility of galactomannan antigen in the bronchial washing and serum for diagnosing pulmonary aspergillosis. Respir Med 2013;107:1094-100.

34. Maestrelli P, Saetta M, Di Stefano A, et al. Comparison of leukocyte counts in sputum, bronchial biopsies, and bronchoalveolar lavage. Am J Respir Crit Care Med 1995;152:1926-31.

35. Konstan MW, Hilliard KA, Norvell TM, et al. Bronchoalveolar lavage findings in cystic fibrosis patients with stable, clinically mild lung disease suggest ongoing infection and inflammation. Am J Respir Crit Care Med 1994;150:448-54.

36. Burmester H, Brinkmann F, Schwerk N, et al. Bronchoscopic findings in children with primary ciliary dyskinesia: Most but not all patients have bacterial bronchitis. ERJ 2012;40.

37. Torre O, Harari S. The diagnosis of cystic lung diseases: a role for bronchoalveolar lavage and transbronchial biopsy? Respir Med 2010;104 Suppl 1:S81-5.

38. Bonetti F, Chiodera PL, Pea M, et al. Transbronchial biopsy in lymphangiomyomatosis of the lung. HMB45 for diagnosis. Am J Surg Pathol 1993;17:1092-102.

39. Meyer FJ, Teschler H, Schnabel R, et al. Bronchoalveolar lavage cytology in pulmonary fibrosis associated with neurofibromatosis. Respir Med 1996;90:365-7.

40. Auerswald U, Barth J, Magnussen H. Value of CD1-positive cells in bronchoalveolar lavage fluid for the diagnosis of pulmonary histiocytosis X. Lung 1991;169:305-9.

41. Baqir M, Vassallo R, Maldonado F, et al. Utility of bronchoscopy in pulmonary Langerhans cell histiocytosis. J Bronchology Interv Pulmonol 2013;20:309-12.

42. Tazi A. Adult pulmonary Langerhans' cell histiocytosis. Eur Respir J 2006;27:1272-85.

43. Geissmann F, Lepelletier Y, Fraitag S, et al. Differentiation of Langerhans cells in Langerhans cell histiocytosis. Blood 2001;97:1241-8.

44. Flint A, Lloyd RV, Colby TV, et al. Pulmonary histiocytosis X. Immunoperoxidase staining for HLADR antigen and S100 protein. Arch Pathol Lab Med 1986;110:930-3.

45. Travis WD, Borok Z, Roum JH, et al. Pulmonary Langerhans cell granulomatosis (histiocytosis X). A clinicopathologic study of 48 cases. Am J Surg Pathol 1993;17:971-86.

46. Hamzaoui K, Berraies A, Kaabachi W, et al. Pulmonary manifestations in Behcet disease: impaired natural killer cells activity. Multidiscip Respir Med 2013;8:29.

47. Bertorelli G, Pesci A, Manganelli P, et al. Subclinical pulmonary involvement in essential mixed cryoglobulinemia assessed by bronchoalveolar lavage. Chest 1991;100:1478-9.

48. Manganelli P, Salaffi F, Subiaco S, et al. Bronchoalveolar lavage in mixed cryoglobulinaemia associated with hepatitis C virus. Br J Rheumatol 1996;35:978-82.

49. Allen JN, Davis WB. Eosinophilic lung diseases. Am J Respir Crit Care Med 1994;150:1423-38.

50. Hoffman GS, Sechler JM, Gallin JI, et al. Bronchoalveolar lavage analysis in Wegener's granulomatosis. A method to study disease pathogenesis. Am Rev Respir Dis 1991;143:401-7.

51. Schnabel A, Reuter M, Gloeckner K, et al. Bronchoalveolar lavage cell profiles in Wegener's granulomatosis. Respir 
Med 1999;93:498-506.

52. Ramsey J, Amari M, Kantrow SP. Pulmonary vasculitis: clinical presentation, differential diagnosis, and management. Curr Rheumatol Rep 2010;12:420-8.

53. Philit F, Etienne-Mastroianni B, Parrot A, et al. Idiopathic acute eosinophilic pneumonia: a study of 22 patients. Am J Respir Crit Care Med 2002;166:1235-9.

54. Pope-Harman AL, Davis WB, Allen ED, et al. Acute eosinophilic pneumonia. A summary of 15 cases and review of the literature. Medicine (Baltimore) 1996;75:334-42.

55. Bonaccorsi A, Cancellieri A, Chilosi M, et al. Acute interstitial pneumonia: report of a series. Eur Respir J 2003;21:187-91.

56. Pesci A, Bertorelli G, Manganelli P, et al. Bronchoalveolar lavage in chronic eosinophilic pneumonia. Analysis of six cases in comparison with other interstitial lung diseases. Respiration 1988;54 Suppl 1:16-22.

57. Lazor R, Vandevenne A, Pelletier A, et al. Cryptogenic organizing pneumonia. Characteristics of relapses in a series of 48 patients. The Groupe d'Etudes et de Recherche sur les Maladles "Orphelines" Pulmonaires (GERM"O"P). Am J Respir Crit Care Med 2000;162:571-7.

58. Poletti V, Cazzato S, Minicuci N, et al. The diagnostic value of bronchoalveolar lavage and transbronchial lung biopsy in cryptogenic organizing pneumonia. Eur Respir J 1996;9:2513-6.

59. Cohen AJ, King TE Jr, Downey GP. Rapidly progressive bronchiolitis obliterans with organizing pneumonia. Am J Respir Crit Care Med 1994;149:1670-5.

60. Cazzato S, Zompatori M, Baruzzi G, et al. Bronchiolitis obliterans-organizing pneumonia: an Italian experience. Respir Med 2000;94:702-8.

61. Ravaglia C, Tomassetti S, Casoni G, et al. BAL findings in desquamative interstitial pneumonia (DIP) and other idiopathic interstitial pneumonia (IIP). ERJ 2014;44.

62. Wessendorf T, Bonella F, Theegarten D, et al. Usefulness of bronchoalveolar lavage in the diagnosis of desquamative interstitial pneumonia. ERJ 2014;44.

63. Bouvry D, Mouthon L, Brillet PY, et al. Granulomatosisassociated common variable immunodeficiency disorder: a case-control study versus sarcoidosis. Eur Respir J 2013;41:115-22.

64. Manganelli P, Bertorelli G, Fietta P, et al. Interstitial lung disease in connective tissue inflammation. Evaluation by means of bronchoalveolar lavage. Recenti Prog Med 1988;79:424-9.

65. Ikeda S, Arita M, Morita M, et al. Interstitial lung disease in clinically amyopathic dermatomyositis with and without
anti-MDA-5 antibody: to lump or split? BMC Pulm Med 2015;15:159.

66. Mukae H, Ishimoto H, Sakamoto N, et al. Clinical differences between interstitial lung disease associated with clinically amyopathic dermatomyositis and classic dermatomyositis. Chest 2009;136:1341-7.

67. Ishioka S, Inyaku K, Shirotani Y, et al. Bronchoalveolar lavage fluid findings in rheumatoid arthritis. Nihon Kyobu Shikkan Gakkai Zasshi 1992;30:614-8.

68. Pesci A, Bertorelli G, Manganelli P, et al. Bronchoalveolar lavage analysis of interstitial lung disease in CREST syndrome. Clin Exp Rheumatol 1986;4:121-4.

69. Salaffi F, Manganelli P, Carotti M, et al. A longitudinal study of pulmonary involvement in primary Sjogren's syndrome: relationship between alveolitis and subsequent lung changes on high-resolution computed tomography. Br J Rheumatol 1998;37:263-9.

70. Behr J, Vogelmeier C, Beinert T, et al. Bronchoalveolar lavage for evaluation and management of scleroderma disease of the lung. Am J Respir Crit Care Med 1996;154:400-6.

71. Kowal-Bielecka O, Kowal K, Highland KB, et al. Bronchoalveolar lavage fluid in scleroderma interstitial lung disease: technical aspects and clinical correlations: review of the literature. Semin Arthritis Rheum 2010;40:73-88.

72. Silver RM, Miller KS, Kinsella MB, et al. Evaluation and management of scleroderma lung disease using bronchoalveolar lavage. Am J Med 1990;88:470-6.

73. Cha SI, Fessler MB, Cool CD, et al. Lymphoid interstitial pneumonia: clinical features, associations and prognosis. Eur Respir J 2006;28:364-9.

74. Pisani RJ, Witzig TE, Li CY, et al. Confirmation of lymphomatous pulmonary involvement by immunophenotypic and gene rearrangement analysis of bronchoalveolar lavage fluid. Mayo Clin Proc 1990;65:651-6.

75. Gülhan B, Ozçelik U, Gürakan F, et al. Different features of lung involvement in Niemann-Pick disease and Gaucher disease. Respir Med 2012;106:1278-85.

76. Shimizu S, Yoshinouchi T, Ohtsuki Y, et al. The appearance of S-100 protein-positive dendritic cells and the distribution of lymphocyte subsets in idiopathic nonspecific interstitial pneumonia. Respir Med 2002;96:770-6.

77. Veeraraghavan S, Latsi PI, Wells AU, et al. BAL findings in idiopathic nonspecific interstitial pneumonia and usual interstitial pneumonia. Eur Respir J 2003;22:239-44. 
78. Nagai S, Kitaichi M, Itoh H, et al. Idiopathic nonspecific interstitial pneumonia/fibrosis: comparison with idiopathic pulmonary fibrosis and BOOP. Eur Respir J 1998;12:1010-9.

79. Costabel U, Guzman J. Bronchoalveolar lavage in interstitial lung disease. Curr Opin Pulm Med 2001;7:255-61.

80. Oda T, Ogura T, Kitamura H, et al. Distinct characteristics of pleuroparenchymal fibroelastosis with usual interstitial pneumonia compared with idiopathic pulmonary fibrosis. Chest 2014;146:1248-55.

81. Sieminska A, Kuziemski K. Respiratory bronchiolitisinterstitial lung disease. Orphanet J Rare Dis 2014;9:106.

82. Ohshimo S, Bonella F, Cui A, et al. Significance of bronchoalveolar lavage for the diagnosis of idiopathic pulmonary fibrosis. Am J Respir Crit Care Med 2009; 179:1043-7.

83. Kinder BW, Brown KK, Schwarz MI, et al. Baseline BAL neutrophilia predicts early mortality in idiopathic pulmonary fibrosis. Chest 2008;133:226-32.

84. Vathesatogkit P, Harkin TJ, Addrizzo-Harris DJ, et al. Clinical correlation of asbestos bodies in BAL fluid. Chest 2004;126:966-71.

85. Wallace JM, Oishi JS, Barbers RG, et al. Bronchoalveolar lavage cell and lymphocyte phenotype profiles in healthy asbestos-exposed shipyard workers. Am Rev Respir Dis 1989;139:33-8.

86. Corhay JL, Delavignette JP, Bury T, et al. Occult exposure to asbestos in steel workers revealed by bronchoalveolar lavage. Arch Environ Health 1990;45:278-82.

87. Karjalainen A, Anttila S, Mantyla T, et al. Asbestos bodies in bronchoalveolar lavage fluid in relation to occupational history. Am J Ind Med 1994;26:645-54.

88. Balmes JR, Abraham JL, Dweik RA, et al. An official American Thoracic Society statement: diagnosis and management of beryllium sensitivity and chronic beryllium disease. Am J Respir Crit Care Med 2014;190:e34-59.

89. Baur X, Borsch-Galetke E, Raulf M, et al. Occupationaltype exposure tests and bronchoalveolar lavage analyses in two patients with byssinosis and two asymptomatic cotton workers. Int Arch Occup Environ Health 1993;65:141-6.

90. Schreiber J, Koschel D, Kekow J, et al. Rheumatoid pneumoconiosis (Caplan's syndrome). Eur J Intern Med 2010;21:168-72.

91. Castranova V, Vallyathan V. Silicosis and coal workers' pneumoconiosis. Environ Health Perspect 2000;108 Suppl 4:675-84.

92. Kayacan O, Beder S, Karnak D. Cellular profile of bronchoalveolar lavage fluid in Turkish miners. Postgrad Med J 2003;79:527-30.

93. Vallyathan V, Goins M, Lapp LN, et al. Changes in bronchoalveolar lavage indices associated with radiographic classification in coal miners. Am J Respir Crit Care Med 2000;162:958-65.

94. Mizutani RF, Goncalves C, Leao BD, et al. Hard metal lung disease - Role of bronchoalveolar lavage in the diagnosis. ERJ 2014;44.

95. Mizutani RF, Terra-Filho M, Lima E, et al. Hard metal lung disease: a case series. J Bras Pneumol 2016;42:447-52.

96. Nemery B, Verbeken EK, Demedts M. Giant cell interstitial pneumonia (hard metal lung disease, cobalt lung). Semin Respir Crit Care Med 2001;22:435-48.

97. Ohori NP, Sciurba FC, Owens GR, et al. Giant-cell interstitial pneumonia and hard-metal pneumoconiosis. A clinicopathologic study of four cases and review of the literature. Am J Surg Pathol 1989;13:581-7.

98. Caillaud DM, Vergnon JM, Madroszyk A, et al. Bronchoalveolar lavage in hypersensitivity pneumonitis: a series of 139 patients. Inflamm Allergy Drug Targets 2012;11:15-9.

99. Lacasse Y, Cormier Y. Hypersensitivity pneumonitis. Orphanet J Rare Dis 2006;1:25.

100. Yoshizawa Y, Ohtani Y, Hayakawa H, et al. Chronic hypersensitivity pneumonitis in Japan: a nationwide epidemiologic survey. J Allergy Clin Immunol 1999;103:315-20.

101. Ratjen F, Costabel U, Griese M, et al. Bronchoalveolar lavage fluid findings in children with hypersensitivity pneumonitis. Eur Respir J 2003;21:144-8.

102. Bandici RM, Bandici R, Cioban GC, et al. Lung Siderosis. Med Con 2015;10:43-7.

103. Khalid I, Khalid TJ, Jennings JH. A welder with pneumosiderosis: a case report. Cases J 2009;2:6639.

104. Yoshii C, Matsuyama T, Takazawa A, et al. Welder's pneumoconiosis: diagnostic usefulness of high-resolution computed tomography and ferritin determinations in bronchoalveolar lavage fluid. Intern Med 2002;41:1111-7.

105. Christman JW, Emerson RJ, Graham WG, et al. Mineral dust and cell recovery from the bronchoalveolar lavage of healthy Vermont granite workers. Am Rev Respir Dis 1985;132:393-9.

106.Hnizdo E, Murray J, Sluis-Cremer GK, et al. Correlation between radiological and pathological diagnosis of silicosis: an autopsy population based study. Am J Ind Med 1993;24:427-45.

107. Nugent KM, Dodson RF, Idell S, et al. The utility of 
bronchoalveolar lavage and transbronchial lung biopsy combined with energy-dispersive $\mathrm{X}$-ray analysis in the diagnosis of silicosis. Am Rev Respir Dis 1989;140:1438-41.

108. Morgan GW, Breit SN. Radiation and the lung: a reevaluation of the mechanisms mediating pulmonary injury. Int J Radiat Oncol Biol Phys 1995;31:361-9.

109. Nakayama Y, Makino S, Fukuda Y, et al. Activation of lavage lymphocytes in lung injuries caused by radiotherapy for lung cancer. Int J Radiat Oncol Biol Phys 1996;34:459-67.

110. Kadmon G, Levy I, Mandelboim M, et al. Polymerasechain-reaction-based diagnosis of viral pulmonary infections in immunocompromised children. Acta Paediatr 2013;102:e263-8.

111. Campbell SJ, Kynyk JA, Davis JA. Disseminated adenovirus infection causing severe ARDS. BMJ Case Rep 2017;2017.

112. Ogimi C, Waghmare AA, Kuypers JM, et al. Clinical Significance of Human Coronavirus in Bronchoalveolar Lavage Samples From Hematopoietic Cell Transplant Recipients and Patients With Hematologic Malignancies. Clin Infect Dis 2017;64:1532-9.

113. Memish ZA, Al-Tawfiq JA, Makhdoom HQ, et al. Respiratory tract samples, viral load, and genome fraction yield in patients with Middle East respiratory syndrome. J Infect Dis 2014;210:1590-4.

114.Liao M, Liu Y, Yuan J, et al. Single-cell landscape of bronchoalveolar immune cells in patients with COVID-19. Nat Med 2020;26:842-4.

115. Tan SK, Burgener EB, Waggoner JJ, et al. Molecular and Culture-Based Bronchoalveolar Lavage Fluid Testing for the Diagnosis of Cytomegalovirus Pneumonitis. Open Forum Infect Dis 2016;3:ofv212.

116. Sommerwerck U, Rabis T, Anhenn O, et al. Cytomegalovirus (CMV) infection - Correlation between CMV-DNA PCR in bronchoalveolar lavage (BAL), CMV pp65 antigen load in PBMCs and clinical symptoms in lung transplant recipients. ERJ 2011;38.

117.Levy H, Simpson SQ. Hantavirus pulmonary syndrome. Am J Respir Crit Care Med 1994;149:1710-3.

118. Nolte KB, Feddersen RM, Foucar K, et al. Hantavirus pulmonary syndrome in the United States: a pathological description of a disease caused by a new agent. Hum Pathol 1995;26:110-20.

119. Rasmuson J, Pourazar J, Linderholm M, et al. Presence of activated airway $\mathrm{T}$ lymphocytes in human puumala hantavirus disease. Chest 2011;140:715-22.

120. Rasmuson J, Pourazar J, Mohamed N, et al. Cytotoxic immune responses in the lungs correlate to disease severity in patients with hantavirus infection. Eur J Clin Microbiol Infect Dis 2016;35:713-21.

121. Gizzi M, Delaere B, Weynand B, et al. Another case of "European hantavirus pulmonary syndrome" with severe lung, prior to kidney, involvement, and diagnosed by viral inclusions in lung macrophages. Eur J Clin Microbiol Infect Dis 2013;32:1341-5.

122. Roig IL, Musher DM, Tweardy DJ. Severe pulmonary involvement in a case attributed to domestically acquired Seoul hantavirus in the United States. Clin Infect Dis 2012;54:91-4.

123. Das S, Miller RF. Lymphocytic interstitial pneumonitis in HIV infected adults. Sex Transm Infect 2003;79:88-93.

124.Doffman SR, Miller RF. Interstitial lung disease in HIV. Clin Chest Med 2013;34:293-306.

125. Griffiths MH, Miller RF, Semple SJ. Interstitial pneumonitis in patients infected with the human immunodeficiency virus. Thorax 1995;50:1141-6.

126. Sattler F, Nichols L, Hirano L, et al. Nonspecific interstitial pneumonitis mimicking Pneumocystis carinii pneumonia. Am J Respir Crit Care Med 1997;156:912-7.

127.van den Hoogen BG, van Doornum GJ, Fockens JC, et al. Prevalence and clinical symptoms of human metapneumovirus infection in hospitalized patients. J Infect Dis 2003;188:1571-7.

128. Vargas SO, Kozakewich HP, Perez-Atayde AR, et al. Pathology of human metapneumovirus infection: insights into the pathogenesis of a newly identified respiratory virus. Pediatr Dev Pathol 2004;7:478-86; discussion 421.

129. Hunt DP, Muse VV, Pitman MB. Case records of the Massachusetts General Hospital. Case 12-2013. An 18-year-old woman with pulmonary infiltrates and respiratory failure. N Engl J Med 2013;368:1537-45.

130. Sabugo F, Espinoza-Araya R, Meneses MF, et al. Acute herpes simplex virus 1 pneumonitis in a patient with systemic lupus erythematosus. J Clin Rheumatol 2014;20:42-4.

131. Tachikawa R, Tomii K, Seo R, et al. Detection of herpes viruses by multiplex and real-time polymerase chain reaction in bronchoalveolar lavage fluid of patients with acute lung injury or acute respiratory distress syndrome. Respiration 2014;87:279-86.

132.Linssen CF, Jacobs JA, Stelma FF, et al. Herpes simplex virus load in bronchoalveolar lavage fluid is related to poor outcome in critically ill patients. Intensive Care Med 2008;34:2202-9.

133. Luyt CE, Combes A, Deback C, et al. Herpes simplex virus lung infection in patients undergoing prolonged 
mechanical ventilation. Am J Respir Crit Care Med 2007;175:935-42.

134. Faverio P, Aliberti S, Ezekiel C, et al. Influenza A/H1N1 Severe Pneumonia: Novel Morphocytological Findings in Bronchoalveolar Lavage. Interdiscip Perspect Infect Dis 2014;2014:470825.

135.Pokharel S, Merickel CR, Alatassi H. Parainfluenza virus-3-induced cytopathic effects on lung tissue and bronchoalveolar lavage fluid in a bone marrow transplant recipient: a case report. Diagn Cytopathol 2014;42:521-4.

136. McNamara PS, Ritson P, Selby A, et al. Bronchoalveolar lavage cellularity in infants with severe respiratory syncytial virus bronchiolitis. Arch Dis Child 2003;88:922-6.

137. Shirai T, Sano K, Matsuyama S, et al. Varicella pneumonia in a healthy adult presenting with severe respiratory failure. Intern Med 1996;35:315-8.

138. Cowl CT, Prakash UB, Shawn Mitchell P, et al. Varicellazoster virus detection by polymerase chain reaction using bronchoalveolar lavage specimens. Am J Respir Crit Care Med 2000;162:753-4.

139. Rozental T, Mascarenhas LF, Rozenbaum R, et al. Coxiella burnetii, the agent of $\mathrm{Q}$ fever in Brazil: its hidden role in seronegative arthritis and the importance of molecular diagnosis based on the repetitive element IS1111 associated with the transposase gene. Mem Inst Oswaldo Cruz 2012;107:695-7.

140. Trisolini R, Lazzari Agli L, Cancellieri A, et al. Bronchoalveolar lavage findings in severe communityacquired pneumonia due to Legionella pneumophila serogroup 1. Respir Med 2004;98:1222-6.

141.Hayden RT, Uhl JR, Qian X, et al. Direct detection of Legionella species from bronchoalveolar lavage and open lung biopsy specimens: comparison of LightCycler PCR, in situ hybridization, direct fluorescence antigen detection, and culture. J Clin Microbiol 2001;39:2618-26.

142. Bentz JS, Carroll K, Ward JH, et al. Acid-fast-positive Legionella pneumophila: a possible pitfall in the cytologic diagnosis of mycobacterial infection in pulmonary specimens. Diagn Cytopathol 2000;22:45-8.

143. Helmerhorst HJ, van Tol EN, Tuinman PR, et al. Severe pulmonary manifestation of leptospirosis. Neth $\mathrm{J}$ Med 2012;70:215-21.

144. Marchiori E, Lourenco S, Setubal S, et al. Clinical and imaging manifestations of hemorrhagic pulmonary leptospirosis: a state-of-the-art review. Lung 2011;189:1-9.

145.Paganin F, Gauzere BA, Lugagne N, et al. Bronchoalveolar lavage in rapid diagnosis of leptospirosis. Lancet 1996;347:1562-3.
146. Dolhnikoff M, Mauad T, Bethlem EP, et al. Pathology and pathophysiology of pulmonary manifestations in leptospirosis. Braz J Infect Dis 2007;11:142-8.

147. Koh YY, Park Y, Lee HJ, et al. Levels of interleukin-2, interferon-gamma, and interleukin-4 in bronchoalveolar lavage fluid from patients with Mycoplasma pneumonia: implication of tendency toward increased immunoglobulin E production. Pediatrics 2001;107:E39.

148. Schmitt BH, Sloan LM, Patel R. Real-time PCR detection of Mycoplasma pneumoniae in respiratory specimens. Diagn Microbiol Infect Dis 2013;77:202-5.

149.Mishra R, Cano E, Venkatram S, et al. An interesting case of mycoplasma pneumonia associated multisystem involvement and diffuse alveolar hemorrhage. Respir Med Case Rep 2017;21:78-81.

150.Johansson A, Berglund L, Eriksson U, et al. Comparative analysis of PCR versus culture for diagnosis of ulceroglandular tularemia. J Clin Microbiol 2000;38:22-6.

151. Boersma WG, Erjavec Z, van der Werf TS, et al. Bronchoscopic diagnosis of pulmonary infiltrates in granulocytopenic patients with hematologic malignancies: BAL versus PSB and PBAL. Respir Med 2007;101:317-25.

152. Nguyen MH, Jaber R, Leather HL, et al. Use of bronchoalveolar lavage to detect galactomannan for diagnosis of pulmonary aspergillosis among nonimmunocompromised hosts. J Clin Microbiol 2007;45:2787-92.

153. Martynowicz MA, Prakash UB. Pulmonary blastomycosis: an appraisal of diagnostic techniques. Chest 2002;121:768-73.

154. Frost HM, Novicki TJ. Blastomyces Antigen Detection for Diagnosis and Management of Blastomycosis. J Clin Microbiol 2015;53:3660-2.

155.el-Ebiary M, Torres A, Fabregas N, et al. Significance of the isolation of Candida species from respiratory samples in critically ill, non-neutropenic patients. An immediate postmortem histologic study. Am J Respir Crit Care Med 1997;156:583-90.

156. DiTomasso JP, Ampel NM, Sobonya RE, et al. Bronchoscopic diagnosis of pulmonary coccidioidomycosis. Comparison of cytology, culture, and transbronchial biopsy. Diagn Microbiol Infect Dis 1994;18:83-7.

157. Sobonya RE, Barbee RA, Wiens J, et al. Detection of fungi and other pathogens in immunocompromised patients by bronchoalveolar lavage in an area endemic for coccidioidomycosis. Chest 1990;97:1349-55.

158. Maesaki S, Kohno S, Mashimoto H, et al. Detection of Cryptococcus neoformans in bronchial lavage cytology: report of four cases. Intern Med 1995;34:54-7. 
159. Baughman RP, Rhodes JC, Dohn MN, et al. Detection of cryptococcal antigen in bronchoalveolar lavage fluid: a prospective study of diagnostic utility. Am Rev Respir Dis 1992;145:1226-9.

160. Hage CA, Davis TE, Fuller D, et al. Diagnosis of histoplasmosis by antigen detection in BAL fluid. Chest 2010;137:623-8.

161. Dahiya S, Mathur SR, Iyer VK, et al. Diagnosis of Pneumocystis pneumonia by bronchoalveolar lavage cytology: experience at a tertiary care centre in India. Indian J Chest Dis Allied Sci 2005;47:259-65.

162. Golden JA, Hollander H, Stulbarg MS, et al. Bronchoalveolar lavage as the exclusive diagnostic modality for Pneumocystis carinii pneumonia. A prospective study among patients with acquired immunodeficiency syndrome. Chest 1986;90:18-22.

163. Jacobs JA, Dieleman MM, Cornelissen EI, et al. Bronchoalveolar lavage fluid cytology in patients with Pneumocystis carinii pneumonia. Acta Cytol 2001;45:317-26.

164.al-Abbadi MA, Russo K, Wilkinson EJ. Pulmonary mucormycosis diagnosed by bronchoalveolar lavage: a case report and review of the literature. Pediatr Pulmonol 1997;23:222-5.

165. Glazer M, Nusair S, Breuer R, et al. The role of BAL in the diagnosis of pulmonary mucormycosis. Chest 2000;117:279-82.

166. Pirisi M, Gutierrez Y, Minini C, et al. Fatal human pulmonary infection caused by an Angiostrongylus-like nematode. Clin Infect Dis 1995;20:59-65.

167. Sidhu G. Pulmonary Manifestations of Tropical Parasitic Diseases. Medicine Update. 2013.

168.Lall M, Sahni AK, Rajput AK. Pleuropulmonary paragonimiasis: mimicker of tuberculosis. Pathog Glob Health 2013;107:40-2.

169.Procop GW, Marty AM, Scheck DN, et al. North American paragonimiasis. A case report. Acta Cytol 2000;44:75-80.

170.Apewokin S, Steciuk M, Griffin S, et al. Strongyloides hyperinfection diagnosed by bronchoalveolar lavage in an immunocompromized host. Cytopathology 2010;21:345-7.

171. Williams J, Nunley D, Dralle W, et al. Diagnosis of pulmonary strongyloidiasis by bronchoalveolar lavage. Chest 1988;94:643-4.

172. Roig J, Romeu J, Riera C, et al. Acute eosinophilic pneumonia due to toxocariasis with bronchoalveolar lavage findings. Chest 1992;102:294-6.

173.Jacobs F, Depierreux M, Goldman M, et al. Role of bronchoalveolar lavage in diagnosis of disseminated toxoplasmosis. Rev Infect Dis 1991;13:637-41.

174. Ozaki T, Nakahira S, Tani K, et al. Differential cell analysis in bronchoalveolar lavage fluid from pulmonary lesions of patients with tuberculosis. Chest 1992;102:54-9.

175. Sharma SK, Pande JN, Verma K. Bronchoalveolar lavage (BAL) in miliary tuberculosis. Tubercle 1988;69:175-8.

176. Tsao TC, Chen CH, Hong JH, et al. Shifts of T4/T8 $\mathrm{T}$ lymphocytes from BAL fluid and peripheral blood by clinical grade in patients with pulmonary tuberculosis. Chest 2002;122:1285-91.

177. Sugunaraj J, Greco CS, Mehta YB. Rare case of pulmonary infection by rapidly growing mycobacteria in an immunocompromised host. Am J Respir Crit Care Med 2016;193:A3753.

178. Yamazaki Y, Kubo K, Sekiguchi M, et al. Analysis of BAL fluid in M. avium-intracellulare infection in individuals without predisposing lung disease. Eur Respir J 1998;11:1227-31.

179. Yamazaki Y, Kubo K, Takamizawa A, et al. Markers indicating deterioration of pulmonary Mycobacterium avium-intracellulare infection. Am J Respir Crit Care Med 1999;160:1851-5.

180. Inomata T, Konno S, Nagai K, et al. Neutrophil predominance in bronchoalveolar lavage fluid is associated with disease severity and progression of HRCT findings in pulmonary Mycobacterium avium infection. PLoS One 2018;13:e0190189.

181. Casanova MJ, Chaparro M, Valenzuela C, et al. Adalimumabinduced interstitial pneumonia in a patient with Crohn's disease. World J Gastroenterol 2015;21:2260-2.

182. Sachdeva A, Matuschak GM. Diffuse alveolar hemorrhage following alemtuzumab. Chest 2008;133:1476-8.

183. Akoun GM, Cadranel JL, Rosenow EC 3rd, et al. Bronchoalveolar lavage cell data in drug-induced pneumonitis. Allerg Immunol (Paris) 1991;23:245-52.

184. Coudert B, Bailly F, Lombard JN, et al. Amiodarone pneumonitis. Bronchoalveolar lavage findings in 15 patients and review of the literature. Chest 1992;102:1005-12.

185.Mermolja M, Rott T, Debeljak A. Cytology of bronchoalveolar lavage in some rare pulmonary disorders: pulmonary alveolar proteinosis and amiodarone pulmonary toxicity. Cytopathology 1994;5:9-16.

186. Ohar JA, Jackson F, Dettenmeier PA, et al. Bronchoalveolar lavage cell count and differential are not reliable indicators of amiodarone-induced pneumonitis. Chest 1992;102:999-1004. 187. Raghavan M, Mazer MA, Brink DJ. Severe hypersensitivity 
pneumonitis associated with anagrelide. Ann Pharmacother 2003;37:1228-31.

188. Ananthakrishnan AN, Attila T, Otterson MF, et al. Severe pulmonary toxicity after azathioprine/6-mercaptopurine initiation for the treatment of inflammatory bowel disease. J Clin Gastroenterol 2007;41:682-8.

189. Patel JN, Jiang C, Hertz DL, et al. Bevacizumab and the risk of arterial and venous thromboembolism in patients with metastatic, castration-resistant prostate cancer treated on Cancer and Leukemia Group B (CALGB) 90401 (Alliance). Cancer 2015;121:1025-31.

190. Sekimoto Y, Kato M, Shukuya T, et al. Bevacizumabinduced chronic interstitial pneumonia during maintenance therapy in non-small cell lung cancer. Respirol Case Rep 2016;4:e00151.

191. White DA, Kris MG, Stover DE. Bronchoalveolar lavage cell populations in bleomycin lung toxicity. Thorax 1987;42:551-2.

192. Boyer JE, Batra RB, Ascensao JL, et al. Severe pulmonary complication after bortezomib treatment for multiple myeloma. Blood 2006;108:1113.

193. Dun X, Yuan Z, Fu W, et al. Severe pulmonary complications after bortezomib treatment in multiple myeloma. Hematol Oncol 2010;28:49-52.

194. Miyakoshi S, Kami M, Yuji K, et al. Severe pulmonary complications in Japanese patients after bortezomib treatment for refractory multiple myeloma. Blood 2006;107:3492-4.

195. Tintner R, Manian P, Gauthier P, et al. Pleuropulmonary fibrosis after long-term treatment with the dopamine agonist pergolide for Parkinson Disease. Arch Neurol 2005;62:1290-5.

196. Vergnon JM, Boucheron S, Riffat J, et al. [Interstitial pneumopathies caused by busulfan. Histologic, developmental and bronchoalveolar lavage analysis of 3 cases]. Rev Med Interne 1988;9:377-83.

197. Schatz PL, Mesologites D, Hyun J, et al. Captoprilinduced hypersensitivity lung disease. An immunecomplex-mediated phenomenon. Chest 1989;95:685-7.

198. Watanabe K, Nishimura K, Shiode M, et al. Captopril, an angiotensin-converting enzyme inhibitor, induced pulmonary infiltration with eosinophilia. Intern Med 1996;35:142-5.

199. Archibald N, Yates B, Murphy D, et al. Carbamazepineinduced interstitial pneumonitis in a lung transplant patient. Respir Med 2006;100:1660-2.

200. O'Driscoll BR, Hasleton PS, Taylor PM, et al. Active lung fibrosis up to 17 years after chemotherapy with carmustine
(BCNU) in childhood. N Engl J Med 1990;323:378-82.

201. Chua W, Peters M, Loneragan R, et al. Cetuximabassociated pulmonary toxicity. Clin Colorectal Cancer 2009;8:118-20.

202.Hoag JB, Azizi A, Doherty TJ, et al. Association of cetuximab with adverse pulmonary events in cancer patients: a comprehensive review. J Exp Clin Cancer Res 2009;28:113.

203. Hughes S, Liong J, Miah A, et al. A brief report on the safety study of induction chemotherapy followed by synchronous radiotherapy and cetuximab in stage III nonsmall cell lung cancer (NSCLC): SCRATCH study. J Thorac Oncol 2008;3:648-51.

204. Nishino M, Giobbie-Hurder A, Hatabu H, et al. Incidence of programmed cell death 1 inhibitor-related pneumonitis in patients with advanced cancer:A systematic review and meta-analysis. JAMA Oncol 2016;2:1607-16.

205.Montani D, Seferian A, Parent F, et al. Immune checkpoint inhibitor-associated interstitial lung diseases: some progress but still many issues. Eur Respir J 2017;50:1701319.

206. Cho JY, Kim J, Lee JS, et al. Characteristics, incidence, and risk factors of immune checkpoint inhibitor-related pneumonitis in patients with non-small cell lung cancer. Lung Cancer 2018;125:150-6.

207. Delaunay M, Cadranel J, Lusque A, et al. Immunecheckpoint inhibitors associated interstitial lung disease in cancer patients. Eur Respir J 2017;50:1700050.

208. Tone M, Izumo T, Awano N, et al. High mortality and poor treatment efficacy of immune checkpoint inhibitors in patients with severe grade checkpoint inhibitor pneumonitis in non-small cell lung cancer. Thoracic Cancer 2019;10:2006-12.

209. Crestani B, Jaccard A, Israel-Biet D, et al. Chlorambucilassociated pneumonitis. Chest 1994;105:634-6.

210.Hill BT, Weil AC, Kalaycio M, et al. Pulmonary involvement by chronic lymphocytic leukemia/small lymphocytic lymphoma is a specific pathologic finding independent of inflammatory infiltration. Leuk Lymphoma 2012;53:589-95.

211. Malik SW, Myers JL, DeRemee RA, et al. Lung toxicity associated with cyclophosphamide use. Two distinct patterns. Am J Respir Crit Care Med 1996;154:1851-6.

212.Hamada K, Nagai S, Kitaichi M, et al. Cyclophosphamideinduced late-onset lung disease. Intern Med 2003;42:82-7.

213. Bergeron A, Rea D, Levy V, et al. Lung abnormalities after dasatinib treatment for chronic myeloid leukemia: a case series. Am J Respir Crit Care Med 2007;176:814-8. 
214.Jasielec JK, Larson RA. Dasatinib-Related Pulmonary Toxicity Mimicking an Atypical Infection. J Clin Oncol 2016;34:e46-8.

215. Alsamarai S, Charpidou AG, Matthay RA, et al. Pneumonitis related to docetaxel: case report and review of the literature. In Vivo 2009;23:635-7.

216. Read WL, Mortimer JE, Picus J. Severe interstitial pneumonitis associated with docetaxel administration. Cancer 2002;94:847-53.

217. Jacobs C, Slade M, Lavery B. Doxorubicin and BOOP. A possible near fatal association. Clin Oncol (R Coll Radiol) 2002;14:262.

218. Liu V, White DA, Zakowski MF, et al. Pulmonary toxicity associated with erlotinib. Chest 2007;132:1042-4.

219. Makris D, Scherpereel A, Copin MC, et al. Fatal interstitial lung disease associated with oral erlotinib therapy for lung cancer. BMC Cancer 2007;7:150.

220. Vahid B, Esmaili A. Erlotinib-associated acute pneumonitis: report of two cases. Can Respir J 2007;14:167-70.

221. Cho SK, Oh IH, Park CK, et al. Etanercept induced organizing pneumonia in a patient with rheumatoid arthritis. Rheumatol Int 2012;32:1055-7.

222. Miyagi R, Ideguchi H, Soga T, et al. Development of pulmonary and cardiac sarcoidosis during etanercept therapy. Int J Rheum Dis 2014;17:810-2.

223.Peno-Green L, Lluberas G, Kingsley T, et al. Lung injury linked to etanercept therapy. Chest 2002;122:1858-60.

224. Gurjal A, An T, Valdivieso M, et al. Etoposide-induced pulmonary toxicity. Lung Cancer 1999;26:109-12.

225. Hatakeyama S, Tachibana A, Morita M, et al. [Etoposideinduced pneumonitis]. Nihon Kyobu Shikkan Gakkai Zasshi 1997;35:210-4.

226. Mizuno R, Asano K, Mikami S, et al. Patterns of interstitial lung disease during everolimus treatment in patients with metastatic renal cell carcinoma. Jpn J Clin Oncol 2012;42:442-6.

227. White DA, Schwartz LH, Dimitrijevic S, et al. Characterization of pneumonitis in patients with advanced non-small cell lung cancer treated with everolimus (RAD001). J Thorac Oncol 2009;4:1357-63.

228. Ando M, Okamoto I, Yamamoto N, et al. Predictive factors for interstitial lung disease, antitumor response, and survival in non-small-cell lung cancer patients treated with gefitinib. J Clin Oncol 2006;24:2549-56.

229. Kataoka K, Taniguchi H, Hasegawa Y, et al. Interstitial lung disease associated with gefitinib. Respir Med 2006;100:698-704.
230.Hotta K, Kiura K, Takigawa N, et al. Comparison of the incidence and pattern of interstitial lung disease during erlotinib and gefitinib treatment in Japanese Patients with non-small cell lung cancer: the Okayama Lung Cancer Study Group experience. J Thorac Oncol 2010;5:179-84.

231. Tomioka R, King TE, Jr. Gold-induced pulmonary disease: clinical features, outcome, and differentiation from rheumatoid lung disease. Am J Respir Crit Care Med 1997;155:1011-20.

232. Scott DL, Bradby GV, Aitman TJ, et al. Relationship of gold and penicillamine therapy to diffuse interstitial lung disease. Ann Rheum Dis 1981;40:136-41.

233. Internullo M, Giannelli V, Sardo L, et al. Hydroxyureainduced interstitial pneumonitis: case report and review of the literature. Eur Rev Med Pharmacol Sci 2014;18:190-3.

234. Sandhu HS, Barnes PJ, Hernandez P. Hydroxyureainduced hypersensitivity pneumonitis: A case report and literature review. Can Respir J 2000;7:491-5.

235. Peerzada MM, Spiro TP, Daw HA. Pulmonary toxicities of tyrosine kinase inhibitors. Clin Adv Hematol Oncol 2011;9:824-36.

236. Berthod G, Lazor R, Letovanec I, et al. Pulmonary sarcoid-like granulomatosis induced by ipilimumab. J Clin Oncol 2012;30:e156-9.

237. Barjaktarevic IZ, Qadir N, Suri A, et al. Organizing pneumonia as a side effect of ipilimumab treatment of melanoma. Chest 2013;143:858-61.

238. Chung CU, Park DI, Lee CS, et al. Isoniazid and pulmonary fibrosis. Chin Med J (Engl) 2015;128:702-3.

239. Umeda N, Inada Y, Mamoto T. [Development of eosinophilic pneumonia in a patient with latent tuberculosis infection resulting from isoniazid]. Kekkaku 2014;89:777-80.

240. Chen Y, Kiatsimkul P, Nugent K, et al. Lenalidomideinduced interstitial lung disease. Pharmacotherapy 2010;30:325.

241.Lerch E, Gyorik S, Feilchenfeldt J, et al. A case of lenalidomide-induced hypersensitivity pneumonitis. Onkologie 2010;33:249-52.

242.Akasheh MS, Freytes CO, Vesole DH. Melphalanassociated pulmonary toxicity following high-dose therapy with autologous hematopoietic stem cell transplantation. Bone Marrow Transplant 2000;26:1107-9.

243. Westerfield BT, Michalski JP, McCombs C, et al. Reversible melphalan-induced lung damage. Am J Med 1980;68:767-71.

244. Schnabel A, Richter C, Bauerfeind S, et al. Bronchoalveolar lavage cell profile in methotrexate induced pneumonitis. 
Thorax 1997;52:377-9.

245.Jakubovic BD, Donovan A, Webster PM, et al. Methotrexate-induced pulmonary toxicity. Can Respir J 2013;20:153-5.

246. Silberstein SD. Methysergide. Cephalalgia 1998;18:421-35.

247. Holmberg L, Boman G. Pulmonary reactions to nitrofurantoin. 447 cases reported to the Swedish Adverse Drug Reaction Committee 1966-1976. Eur J Respir Dis 1981;62:180-9.

248. Sovijärvi AR, Lemola M, Stenius B, et al. Nitrofurantoininduced acute, subacute and chronic pulmonary reactions. Scand J Respir Dis 1977;58:41-50.

249. Padley SP, Adler B, Hansell DM, et al. High-resolution computed tomography of drug-induced lung disease. Clin Radiol 1992;46:232-6.

250. Nishino M, Ramaiya NH, Awad MM, et al. PD-1 Inhibitor-Related Pneumonitis in Advanced Cancer Patients: Radiographic Patterns and Clinical Course. Clin Cancer Res 2016;22:6051-60.

251. Shibaki R, Akamatsu H, Fujimoto M, et al. Nivolumab induced radiation recall pneumonitis after two years of radiotherapy. Ann Oncol 2017;28:1404-5.

252.Zitnik RJ, Cooper JA Jr. Pulmonary disease due to antirheumatic agents. Clin Chest Med 1990;11:139-50.

253. Barber NA, Ganti AK. Pulmonary toxicities from targeted therapies: a review. Target Oncol 2011;6:235-43.

254. Bonanni A, Bertelli E, Panicucci C, et al. Ofatumumabassociated acute pneumonitis: Not new but still the first case. Pharmacol Res Perspect 2016;5:e0267.

255. Fujimori K, Yokoyama A, Kurita Y, et al. Paclitaxelinduced cell-mediated hypersensitivity pneumonitis. Diagnosis using leukocyte migration test, bronchoalveolar lavage and transbronchial lung biopsy. Oncology 1998;55:340-4.

256. Sotiriou C, van Houtte P, Klastersky J. Lung fibrosis induced by paclitaxel. Support Care Cancer 1998;6:68-71.

257. Fragkou P, Souli M, Theochari M, et al. A Case of Organizing Pneumonia (OP) Associated with Pembrolizumab. Drug Target Insights 2016;10:9-12.

258. Leroy V, Templier C, Faivre JB, et al. Pembrolizumabinduced pneumonitis. ERJ Open Res 2017;3.

259.Zitnik RJ, Matthay RA. Drug-Induced Lung Disease. 3 ed. Interstitial Lung Disease. Hamilton, Ontario: Mosby Yearbook, 1998.

260. Dixit R, Dixit K, Nuwal P, et al. Diphenylhydantoin (phenytoin)-induced chronic pulmonary disease. Lung India 2009;26:155-8.

261.Periwal P, Joshi S, Gothi R, et al. Phenytoin-induced acute hypersensitivity pneumonitis. Lung India 2015;32:631-4.

262. Dhillon SS, Singh D, Doe N, et al. Diffuse alveolar hemorrhage and pulmonary capillaritis due to propylthiouracil. Chest 1999;116:1485-8.

263.Lioté H, Liote F, Seroussi B, et al. Rituximab-induced lung disease: A systematic literature review. Eur Respir J 2010;35:681-7.

264.Ennishi D, Terui Y, Yokoyama M, et al. Increased incidence of interstitial pneumonia by CHOP combined with rituximab. Int J Hematol 2008;87:393-7.

265. Burton C, Kaczmarski R, Jan-Mohamed R. Interstitial pneumonitis related to rituximab therapy. $\mathrm{N}$ Engl J Med 2003;348:2690-1; discussion 2691.

266. Morelon E, Stern M, Israel-Biet D, et al. Characteristics of sirolimus-associated interstitial pneumonitis in renal transplant patients. Transplantation 2001;72:787-90.

267. Weiner SM, Sellin L, Vonend O, et al. Pneumonitis associated with sirolimus: clinical characteristics, risk factors and outcome--a single-centre experience and review of the literature. Nephrol Dial Transplant 2007;22:3631-7.

268. Takeda H, Nishikawa H, Iguchi E, et al. Sorafenib-induced acute interstitial pneumonia in patients with advanced hepatocellular carcinoma: report of three cases. Clin J Gastroenterol 2012;5:407-12.

269.Parry SD, Barbatzas C, Peel ET, et al. Sulphasalazine and lung toxicity. Eur Respir J 2002;19:756-64.

270.Uluba B, Sahin G, Ozer C, et al. Bronchiolitis obliterans organizing pneumonia associated with sulfasalazine in a patient with rheumatoid arthritis. Clin Rheumatol 2004;23:249-51.

271. Valcke Y, Pauwels R, Van der Straeten M. Bronchoalveolar lavage in acute hypersensitivity pneumonitis caused by sulfasalazine. Chest 1987;92:572-3.

272. Yuasa T, Kitsukawa S, Sukegawa G, et al. Early onset recall pneumonitis during targeted therapy with sunitinib. BMC Cancer 2013;13:3.

273. Vahid B, Mehrotra A. Trastuzumab (Herceptin)-associated lung injury. Respirology 2006;11:655-8.

274. Kim SJ, Jhun BW, Lee JE, et al. A case of drug-induced interstitial pneumonitis caused by valproic Acid for the treatment of seizure disorders. Tuberc Respir Dis (Seoul) 2014;77:145-8.

275. Choi KH, Nam TS, Kim JT, et al. Valproate associated diffuse alveolar hemorrhage. Eur J Neurol 2011;18:e98-9.

276. Kamenetsky Z, Da'as N, Esayag Y, et al. Valproic acidinduced eosinophilic pleural effusion: a case report and review of the literature. Neurologist 2012;18:39-40. 
277.Artigas A, Castella X. Bronchoalveolar Lavage (BAL) in Adult Respiratory Distress Syndrome (ARDS). Update in Intensive Care and Emergency Medicine. Berlin, Heidelberg: Springer, 1991.

278. Morgan JE, McCaul DS, Rodriguez FH, et al. Pulmonary immunologic features of alveolar septal amyloidosis associated with multiple myeloma. Chest 1987;92:704-8.

279. Corwin RW, Irwin RS. The lipid-laden alveolar macrophage as a marker of aspiration in parenchymal lung disease. Am Rev Respir Dis 1985;132:576-81.

280. Silverman JF, Turner RC, West RL, et al. Bronchoalveolar lavage in the diagnosis of lipoid pneumonia. Diagn Cytopathol 1989;5:3-8.

281. Greenebaum E, Copeland A, Grewal R. Blackened bronchoalveolar lavage fluid in crack smokers. A preliminary study. Am J Clin Pathol 1993;100:481-7.

282. Forrester JM, Steele AW, Waldron JA, et al. Crack lung: an acute pulmonary syndrome with a spectrum of clinical and histopathologic findings. Am Rev Respir Dis 1990;142:462-7.

283. Davies SJ, Gosney JR, Hansell DM, et al. Diffuse idiopathic pulmonary neuroendocrine cell hyperplasia: an under-recognised spectrum of disease. Thorax 2007;62:248-52.

284. Arnaud L, Pierre I, Beigelman-Aubry C, et al. Pulmonary involvement in Erdheim-Chester disease: a single-center study of thirty-four patients and a review of the literature. Arthritis Rheum 2010;62:3504-12.

285. Diamond EL, Dagna L, Hyman DM, et al. Consensus guidelines for the diagnosis and clinical management of Erdheim-Chester disease. Blood 2014;124:483-92.

286. Rouhani FN, Brantly ML, Markello TC, et al. Alveolar macrophage dysregulation in Hermansky-Pudlak syndrome type 1. Am J Respir Crit Care Med 2009;180:1114-21.

287. Takahashi K, Ishida T, Ogura G, et al. Diagnostic usefulness of bronchoalveolar lavage in Hermansky-Pudlak syndrome: a case with double lung cancers. Intern Med 2004;43:972-6.

288. Peros-Golubicic T, Sharma O. Clinical Atlas of Interstitial Lung Disease. 1 ed. Idiopathic Pulmonary Hemosiderosis. London: Springer-Verlag, 2006.

289. Rivera MP, Mehta AC, Wahidi MM. Establishing the diagnosis of lung cancer: Diagnosis and management of lung cancer, 3rd ed: American College of Chest Physicians evidence-based clinical practice guidelines. Chest 2013;143:e142S-65S.

290. Girard P, Caliandro R, Seguin-Givelet A, et al. Sensitivity of cytology specimens from bronchial aspirate or washing during bronchoscopy in diagnosis of lung malignancies:An update. Clin Lung Cancer 2017;18:512-8.

291.Zhang X, Kuang Y, Zhang Y, et al. Shifted focus of bronchoalveolar lavage in patients with suspected thoracic malignancy: an analysis of 224 patients. J Thorac Dis 2016;8:3245-54.

292.Ahmad K, Kumar Gupta M, Dhungel K, et al. Pulmonary alveolar microlithiasis: a rare case report. Iran J Med Sci 2013;38:267-70.

293. Ferreira Francisco FA, Pereira e Silva JL, Hochhegger B, et al. Pulmonary alveolar microlithiasis. State-of-the-art review. Respir Med 2013;107:1-9.

294. Inoue Y, Trapnell BC, Tazawa R, et al. Characteristics of a large cohort of patients with autoimmune pulmonary alveolar proteinosis in Japan. Am J Respir Crit Care Med 2008;177:752-62.

295. Burkhalter A, Silverman JF, Hopkins MB, 3rd, et al. Bronchoalveolar lavage cytology in pulmonary alveolar proteinosis. Am J Clin Pathol 1996;106:504-10.

296. Chou CW, Lin FC, Tung SM, et al. Diagnosis of pulmonary alveolar proteinosis: usefulness of papanicolaou-stained smears of bronchoalveolar lavage fluid. Arch Intern Med 2001;161:562-6.

297. Wang BM, Stern EJ, Schmidt RA, et al. Diagnosing pulmonary alveolar proteinosis. A review and an update. Chest 1997;111:460-6.

298. Schoch OD, Schanz U, Koller M, et al. BAL findings in a patient with pulmonary alveolar proteinosis successfully treated with GM-CSF. Thorax 2002;57:277-80.

299. O'Keefe MC, Post MD. Pulmonary capillary hemangiomatosis: a rare cause of pulmonary hypertension. Arch Pathol Lab Med 2015;139:274-7.

300.Alzghoul B, Li P, Zaki S, et al. Bronchoalveolar Lavage Flow Cytometry for the Diagnosis of Pulmonary PostTransplant Lymphoproliferative Disorder. QJM 2020. [Epub ahead of print].

301. Michelson P, Watkins B, Webber SA, et al. Screening for PTLD in lung and heart-lung transplant recipients by measuring EBV DNA load in bronchoalveolar lavage fluid using real time PCR. Pediatr Transplant 2008;12:464-8.

302.Montani D, Price LC, Dorfmuller P, et al. Pulmonary veno-occlusive disease. Eur Respir J 2009;33:189-200.

303. Rabiller A, Jais X, Hamid A, et al. Occult alveolar haemorrhage in pulmonary veno-occlusive disease. Eur Respir J 2006;27:108-13.

304. Matthews AW, Buchanan R. A case of pulmonary venoocclusive disease and a new bronchoscopic sign. Respir Med 1990;84:503-5. 
305. Kantrow SP, Meyer KC, Kidd P, et al. The CD4/CD8 ratio in BAL fluid is highly variable in sarcoidosis. Eur Respir J 1997;10:2716-21.

306. Winterbauer RH, Lammert J, Selland M, et al. Bronchoalveolar lavage cell populations in the diagnosis of sarcoidosis. Chest 1993;104:352-61.

307.Lewis N, McCaffrey K, Sage K, et al. E-cigarette Use, or Vaping, Practices and Characteristics Among Persons with Associated Lung Injury - Utah, April-October 2019. MMWR Morb Mortal Wkly Rep 2019;68:953-6.

308. Blount BC, Karwowski MP, Morel-Espinosa M, et al. Evaluation of Bronchoalveolar Lavage Fluid from Patients in an Outbreak of E-cigarette, or Vaping, Product UseAssociated Lung Injury - 10 States, August-October 2019. MMWR Morb Mortal Wkly Rep 2019;68:1040-1.

309. Taylor J, Wiens T, Peterson J, et al. Lung Injury Response Task Force. Characteristics of E-cigarette, or Vaping, Products Used by Patients with Associated Lung Injury and Products Seized by Law Enforcement - Minnesota, 2018 and 2019. MMWR Morb Mortal Wkly Rep 2019;68:1096-100.

310. Blount BC, Karwowski MP, Shields PG, et al. Lung Injury Response Laboratory Working Group. Vitamin E Acetate in Bronchoalveolar-Lavage Fluid Associated with EVALI. N Engl J Med 2020;382:697-705.

311.Lal A, Mishra AK, Sahu KK. Vitamin E Acetate and E-Cigarette or Vaping Product-Associated Lung Injury (EVALI): An Update. Am J Med 2020;133:e204.

312.Henry TS, Kanne JP, Kligerman SJ. Imaging of vapingassociated lung disease. N Engl J Med 2019;381:1486-7.

313. Maddock SD, Cirulis MM, Callahan SJ, et al. Pulmonary lipid-laden macrophages and vaping. N Engl J Med 2019;381:1488-9.

314. Davidson K, Brancato A, Heetderks P, et al. Outbreaks of electronic-cigarette-associated acute lipoid pneumonia -

Cite this article as: Davidson KR, Ha DM, Schwarz MI, Chan ED. Bronchoalveolar lavage as a diagnostic procedure: a review of known cellular and molecular findings in various lung diseases. J Thorac Dis 2020;12(9):4991-5019. doi: 10.21037/jtd-20651
North Carolina, July-August 2019. MMWR 2019;68:784-6. 315.von Ranke FM, Zanetti G, Hochhegger B, et al. Infectious diseases causing diffuse alveolar hemorrhage in immunocompetent patients: a state-of-the-art review. Lung 2013;191:9-18.

316. Sato T, Shimosato T, Klinman DM. Silicosis and lung cancer: current perspectives. Lung Cancer (Auckl) 2018;9:91-101.

317. Ozkaya N, Rosenblum MK, Durham BH, et al. The histopathology of Erdheim-Chester disease: a comprehensive review of a molecularly characterized cohort. Mod Pathol 2018;31:581-97.

318. Cordeiro CR, Jones JC, Alfaro T, et al. Bronchoalveolar lavage in occupational lung diseases. Semin Respir Crit Care Med 2007;28:504-13.

319. Tazawa R, Ueda T, Abe M, et al. Inhaled GM-CSF for Pulmonary Alveolar Proteinosis. N Engl J Med 2019;381:923-32.

320. Ramirez RJ, Schultz RB, Dutton RE. Pulmonary alveolar proteinosis. A new technique and rationale for treatment. Arch Intern Med 1963;112:419-31.

321. Nakashima S, Ishimatsu Y, Hara S, et al. Exogenous lipoid pneumonia successfully treated with bronchoscopic segmental lavage therapy. Respir Care 2015;60:e1-5.

322. Kim HJ, Lee WH, Jeong N, et al. Lipoid pneumonitis in a patient with an accidental ingestion of kerosene successfully treated with bronchoscopic segmental lavage and systemic steroid: Case report. Medicine (Baltimore) 2018;97:e12786.

323.Li F, Zhu B, Xie G, et al. Effects of bronchoalveolar lavage on pediatric refractory Mycoplasma pneumoniae pneumonia complicated with atelectasis: a prospective case-control study. Minerva Pediatr 2020. [Epub ahead of print]. 